This document was prepared in conjunction with work accomplished under Contract No. AT(072)-1 with the U.S. Department of Energy.

\title{
DISCLAIMER
}

This report was prepared as an account of work sponsored by an agency of the United States Government. Neither the United States Government nor any agency thereof, nor any of their employees, makes any warranty, express or implied, or assumes any legal liability or responsibility for the accuracy, completeness, or usefulness of any information, apparatus, product or process disclosed, or represents that its use would not infringe privately owned rights. Reference herein to any specific commercial product, process or service by trade name, trademark, manufacturer, or otherwise does not necessarily constitute or imply its endorsement, recommendation, or favoring by the United States Government or any agency thereof. The views and opinions of authors expressed herein do not necessarily state or reflect those of the United States Government or any agency thereof.

This report has been reproduced directly from the best available copy.

Available for sale to the public, in paper, from: U.S. Department of Commerce, National Technical Information Service, 5285 Port Royal Road, Springfield, VA 22161

phone: (800) 553-6847

fax: (703) 605-6900

email: orders@ntis.fedworld.gov

online ordering: http://www.ntis.gov/help/index.asp

Available electronically at http://www.osti.gov/bridge

Available for a processing fee to U.S. Department of Energy and its contractors, in paper, from: U.S. Department of Energy, Office of Scientific and Technical Information, P.O. Box 62, Oak Ridge, TN 37831-0062

phone: (865)576-8401

fax: (865)576-5728

email: reports@adonis.osti.gov 

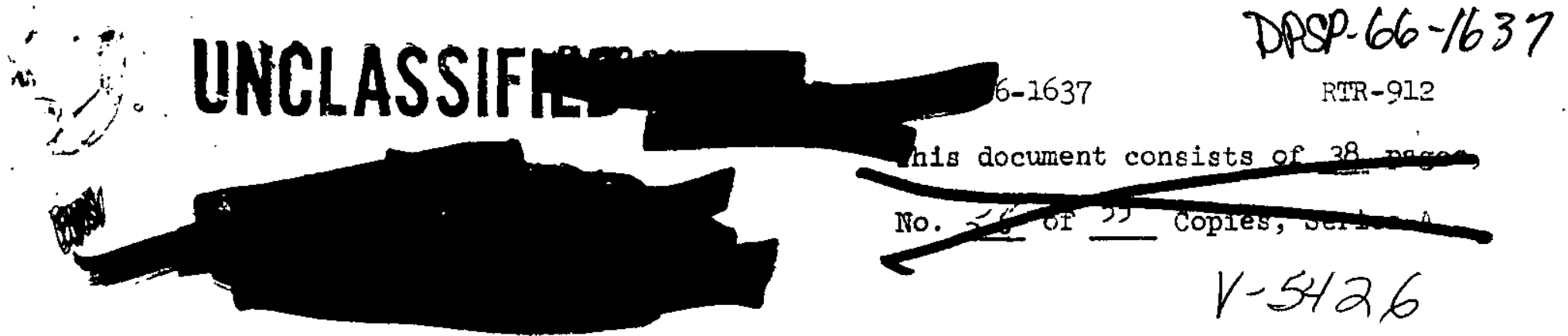

$\mathrm{RTR}-912$

his $6-1637$

No.

document consists of 28 masm

Copy No.:

1. F. P. Allen

2-3. H. W. Bellas

4. J. S. Neill

5. J. W. Croach

6. A. A Johnson

7. E. C. Nelson

8. A. H. Peters

9. D. Baker

10. H. E. Wingo

11. R. C. Thornberry

12. V. Whatley, Jr.

13. H. E. Hootman

14. H. W. Baker

15. J. M. Boswell

16. I. M. Macafee

17. F. E. Kruesi

18. S. Mirshak

19. J. M. Morrison

20. F. D. King

TO: L. W. FOX, 703-A

21. G. F. Merz

22. F. Allen

23. I. G. Anderson

.24. C. T. Axelberg

25. D. R. Becker

26. P. A. Dahlen

27. W. T. Dickenson

28. F. R. Field

29. L. W. Fox

30. G. H. Hair

31. E. H. Judkins

32. E. O. Kiger

33. H. A. Larson

34. J. P. Maloney

35. G. W. McManaway

36. J. T. McMurtrie

37. F. A Nuessle

38. J. H. Nuzum

39. W. M. Oll1ff
40. I. R. Smith

41. R. L. Spessard

42. C. J. Temple

43. 0. A. Tow Jer

4L. J. E. Wall.z

45. W. E. Winter

46. D. A. Ward

47. J. W. Joseph

48. L. H. Wantin

49. R. I. CampbelI

50. R. I. Mayton

51. K. I. Gimmy

52. C. A. Bland

53. Vital Recoras Pile

5h, JRD Central File

(52) $706-\mathrm{CFize}$

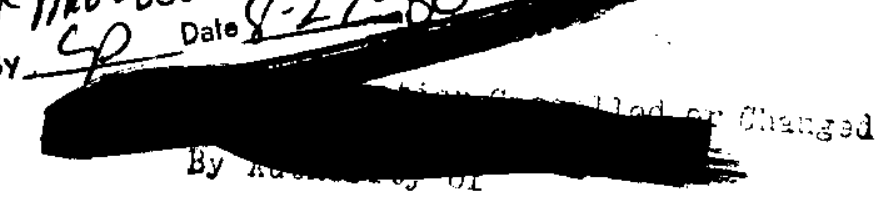

FROM: c. A. BLAND, 706-C@ A

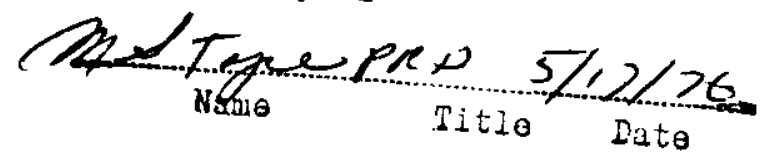

\section{PROCESS SYSTEM HYDRAULICS}

INTRODUCTION

An analysis of hydraulic characteristics of the reactor plenum and the geometry of the permanent tube slots indicates the effect of the plenum pressure gradient on flow is substantially less than has been used previously to determine process water flows from cumulative fuel assembly resistances. The correct process water flows are about $5 \%$ less than those determined from present head available curves (Reference 1) and agree with Bingham pump data reported by the vendor (Reference 2). Better agreement between process water and cooling water heat balances also substantiate the corrected flows (Table 8 ).

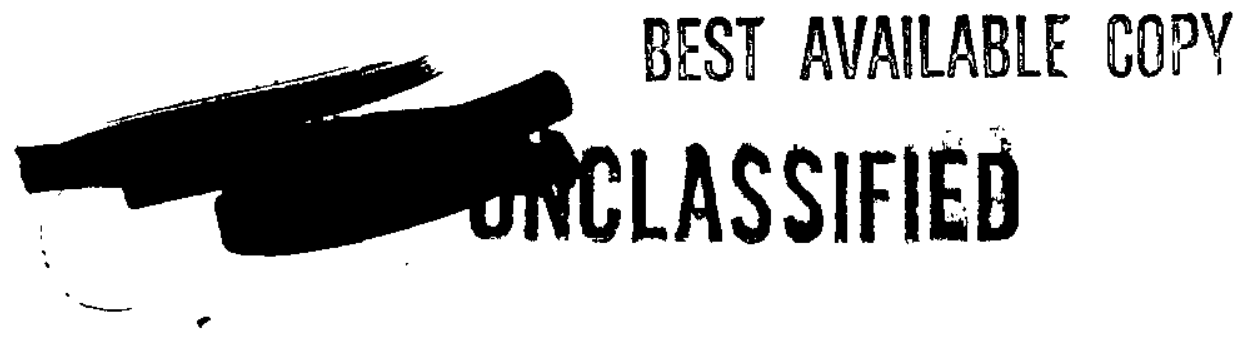


January 24, 1967

L. W. Fox

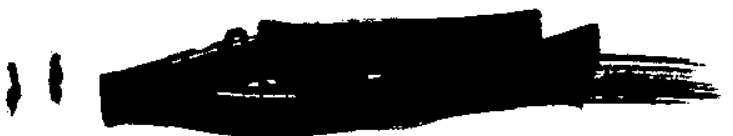

DPSP-66-1637

RTR-912

Process water flow curves have been recalculated using new correlations of system losses based on pressure measurements; revised curves, equations of system losses, and additional hydraulic information are presented in this report.

SUMMARY

A comparison of reactor flows for a full reactor charge (Mark V-R) is summarized below:

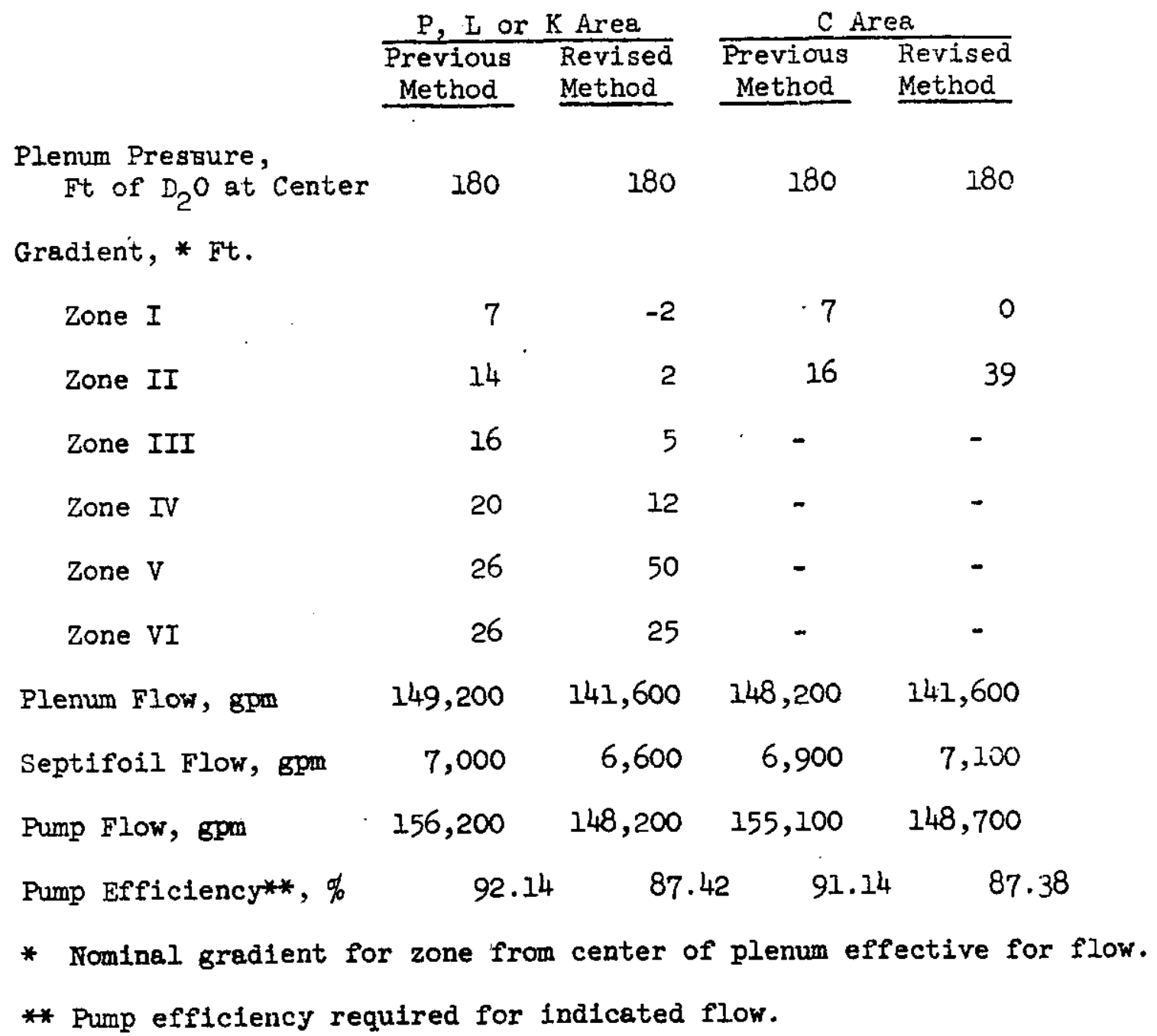

The important points from the above table in comparison of flows from the two methods are:

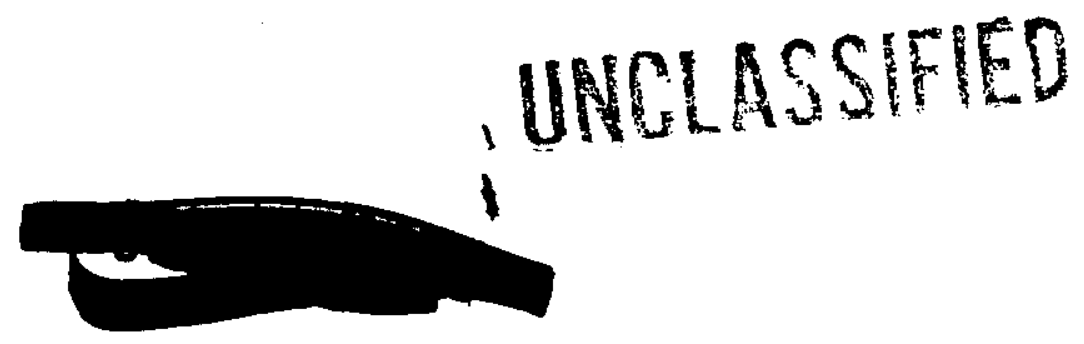




\section{UNCLASSIFIED}

- The major effect on flow is caused by the mean Zone I plenum pressure being 7 to 9 feet less than previously assigned. Of the 600 Mark V-R assemblies, 342 in PIX and 456 in C are in Zone $I$. The plenum pressure gradients are shown in Figures $1,2,3$ and 6 ; previous flows were based on the total head which includes velocity effects that are not wholly effective for flow.

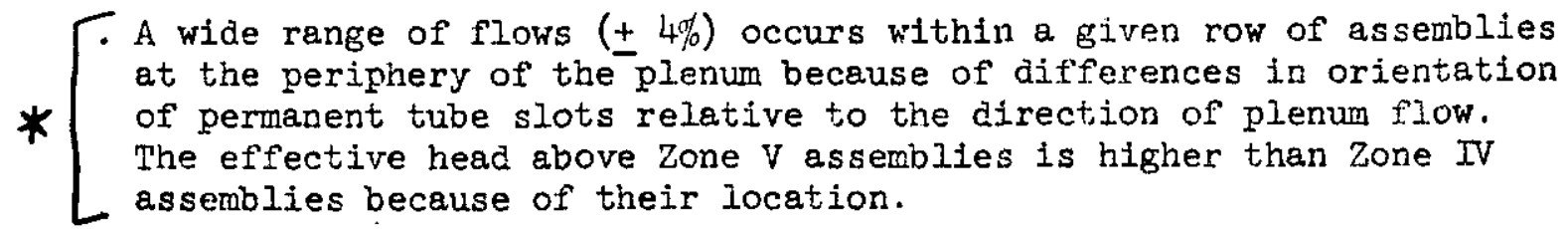

- The septifoil flows are revised because of error in Reference 12. A comparison of $\mathrm{C}$ septifoil flow (73 septifoils) with FLK (61 septifoils) is more reasonable with the revised curves.

- The hydraulics of $C$ are essentially identical to PIK for the same plenum pressure.

This improved calculation method has no significent efiect on current individual fuel assembly operating limits and performance or on charge design because the effects are small, usually conservative, and about, within the allowances that have been made for uncertainty in assembly flow in operating limits.

\section{PROGRAM}

The program for implementing the information presented in this report is as follows:

- Issue revised Technical Standards for Pump Cavitation Linits (Reference 13); have Technical Specification revised.

- Adopt correct head available curves (thereby, revising the specified process water flows) in the reactor areas beginning in January 1967; initial correct flows will be used for the January monthly report (DPSP-67-I-1).

- Collect additional data (flows, pressure, AC motor loads, and heat balance comparisons).

- Convert to this system in describing and planning new charges (SRL.A.OP) as of January 1967.

Conversion to this improved method of flow calculation is desirable because it will result in:

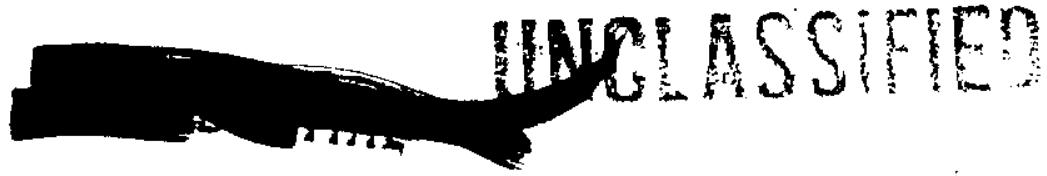


- More consistency of reactor data with SRL/CMX tests.

- Better agreement between heat balance calculations based on process water system and cooling water system.

- Better predictions of operating parameters for special irradiations (mixed lattices).

With adoption of the improved calculation method, it is necessary to remove correction factors from the pump flow rates listed to describe the elbow cavitation curve in Technical Standard DPSTS-105-1.03 and Technical Specification $5 . A .3$ and $5 . B .3$ for PLK. No real change in reactor operation is involved. For example, the Technical limit for a Mark V-R charge (PLK) would remain at $104^{\circ} \mathrm{C}$; the new method of calculating the flow fior the charge would reduce the quoted flow from 158,000 to $150,000 \mathrm{gpm}$. The new standards will reflect this better flow relationship. Limits in operating procedures are related to the measured plenum pressure, and no revision is required.

\section{DISCUSSION}

Discrepancies in process vater flows deternined by different methods were evident in analyses of test data obtained following installation of the Bingham pumps (Reference 3,4, and 5). Anelysis of first test results indicated a difference of about $6 \%$ between flows determined from vendor's pump data and from charge resistance. It was concluded that flow rates determined by charge resistance were more accurate, aIthough the pumping efficiency of $91.7 \%$ (required for the higher flows indicated by this. method) was recognized as suspiciously high.

Reactor flows derived from the earller data were calculated assuming the measured pressure gradient across the plenum (extrapolated for different plenum flow conditions) was effective for flow; this as sumption is incorrect and results in erroneously high flows. The measured pressure gradient, which was the total pressure arop across the plenum, includes the velocity head $\left(\mathrm{v}^{2} / 2 \mathrm{~g}_{\mathrm{c}}\right)$ which is not wholly effective for flow (explained in the following paragraphs). The same incorrect assumption was made in initial hydraulic calculations for the High Flux and Curium II charges; the discrepancy between flows from vendor's data and charge resistance was larger in the small core charges than observed in standard charges because of the larger plenum pressure ( $10 \%$ discrepancy for Curium II see Reference 6).

*An analysis of the effect of slot orientation indicates the total plenum pressure (static head plus velocity head) is not wholly effective for Plow; the effective head is the static head plus some fraction of the plenum velocity head and differs at the entrance to the three permanent tube slots. The fraction of the velocity head effective for forperip

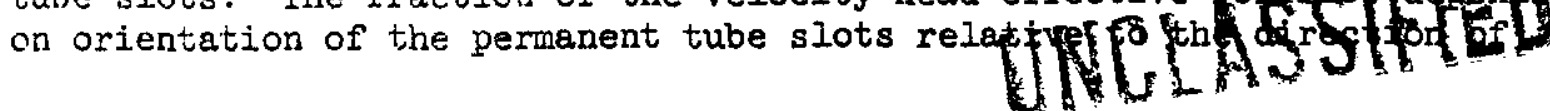


flow. The total pressure, static pressure and nominal effective pressure available (row average for three sjots) for the Curium II charge is shown in Figure 1 ; the nominal effective pressure available for each row of assemblies was calculated by iteration including effects of friction loss across each row of assemblies, vectors of plenum velocities, and fraction of flow through each permanent sleeve slot. Pressure messurements during $\mathrm{K}-13$ within assemblies (Reference 7 ) and distribution of end fitting $\triangle \mathrm{P}^{\prime} \mathrm{s}$ substantiate this effective head curve (Figures 2 and 3 ). The shape of the effective head curve is similar to the static pressure; therefore, the static head curve can be used for approximating the relative flow distribution in full reactor charges (i.e., Mark V-R, VI-E, etc.) with a minimal error (less than $1 \%$ error in total flow which is within the accuracy of hydraulic calculations). A comparison of the static pressure gradient and observed distribution of end-fitting $\triangle P^{\prime} s$ (average $\triangle P$ for similarly-zoned assemblies in a row related to head above the assemblies) for a Mark V-P charge is presented in Figure 6.

The scatter in indicated effective hea in the outer rows of the reactor is attributed to effects of slot orientation and aifferent zoned assemblies; the actual distribution of coolant is also not as well known in this region.

Based on this analysis of the plenum characteristics, the process water system hydraulics were reevaluated using the vendor's data for the Bingham pumps and system pressure measurements at different flows and temperatures (Table 6).

\section{Bingham Pump Date}

The total dynamic head (TDH) and pump efficiency (E) for different pump flows were measured at the Bingham plant for each pump before delivery to SRP. These data are presented in Reference 2 and are summarized in Tables I, 2, 3, and 4 for each area. Average values for all pumps are presented in Table 5. Differences among individual pumps are small (less than $0.5 \%$ from average vaiues); therefore, the average curves were used to develop head available curves. in this report.

\section{Correlation of System Loss Equations}

System pressures at different flow and temperature conditions were used to correlate pressure loss equations for four different segments of the primary system; the data are summarized in Table 6 . The four sections and symbols for pressure losses are as follows:

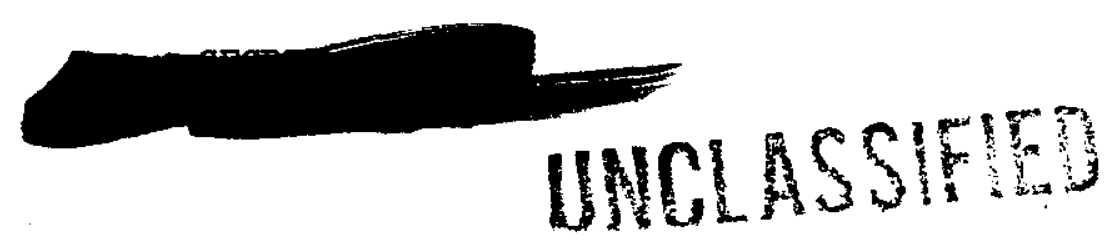


Jenuary 24, 1967

I. W. Fox

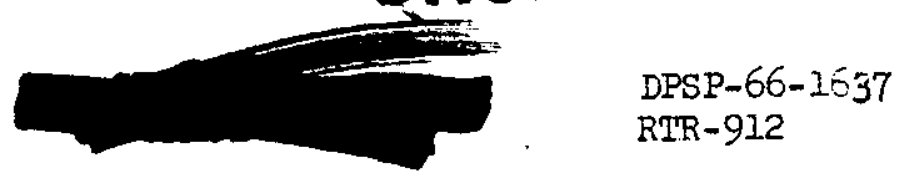

From

Reactor Tank

Pump Discharge Pressure Tap

Heat Exchanger Discharge Tap

Edge of Reactor Plenum
To

Punp Suction Pressure Tap

Heat Exchanger Discharge Tap

Edge of Reactor Plenum

Center of Reactor Plenum
Symbol

$\triangle \mathrm{H}_{\mathrm{S}}$

$\triangle \mathrm{H}_{\mathrm{H}}$

$\triangle \mathrm{H}_{I}$

$\Delta H_{P}$

The relationship of head loss as a function of flow for each segment was correlated in the following form:

$$
\Delta H=C_{1}(\mu / \rho)^{0.2}\left(\frac{Q}{20,000}\right)^{1.8}+C_{2}\left(\frac{Q}{20,000}\right)^{2}
$$

Where:

$$
\begin{aligned}
\Delta H & =\text { Loss in head, Ft of } i_{2} 0 \text { flowing } \\
C_{1}(\mu / P)^{0.2}\left(\frac{Q}{20,000}\right)^{1.8} & =\text { Friction losses sensitive to temperature } \\
\text { (Kinematic viscosit: changes) } & \\
\mathrm{C}_{2}\left(\frac{Q}{20,000}\right)^{2} & =\text { "Square law" losses and Kinetic energy changes } \\
Q & =\text { Individual system flow at average temperature } \\
& \text { of } D_{2} 0 \text { in segment of system, gpm } \\
C_{1} \text { and } \mathrm{C}_{2} & =\text { Constants correlated from measured data } \\
\mu & =\text { Viscosity of fluid, lb/ft-sec } \\
P & =\text { Density of fluid, lb/ft } 3
\end{aligned}
$$

Note: The losses in each segment of the system are calculated in $f t$. of $\mathrm{D}_{2} \mathrm{O}$ at the temperature of flow; the plenum head evailable is the differential head across the pumps less the system losses in equivalent head at $65^{\circ} \mathrm{C}$.

The constants $C_{1}$ and $C_{2}$ were evaluated from measured pressure data and system flows (f $\bar{r}$ om $\triangle$ ir across pump) by regression analysis (calculations are presented in Reference 8). Judgement was necessary in evaluating the aata becouse of suspecval measurement errors.

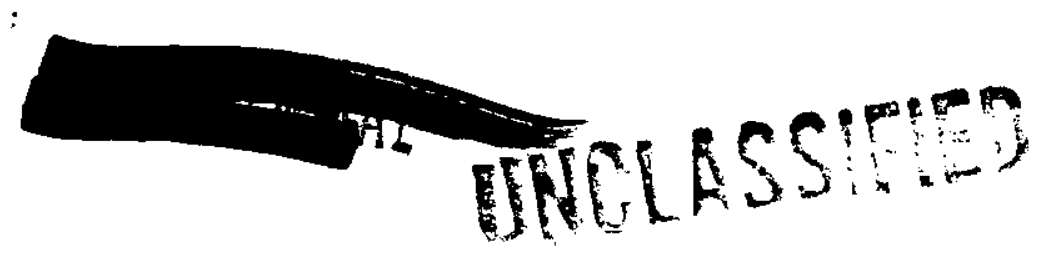


The loss equations for each segment of the system were used to calculate the plenum head available curves shown on Figures 11 and 12 (full charges and Curium II respectively). Equations of septifoil system pressure losses as a function of flow developed in Reference 9 were used for calculating new septifoil flow curves shown on Figures 13 and 14 for full charges and curium II respectively. The sparger jet flow is show in Figure 15 for different plenum pressures.

Reactor Tank to Pump Suction Pressure Tap. The loss in static pressure in the reactor effliuent and pump suction piping is related to flow by the following equations:

$$
\begin{aligned}
& \Delta H_{S}=19.8(\mu / \rho)^{0.2}\left(\frac{Q}{20,000}\right)^{1.8}+7.68\left(\frac{Q}{20,000}\right)^{2} \text { for PIK } \\
& \Delta H_{S}=14.5(\mu / \rho)^{0.2}\left(\frac{Q}{20,000}\right)^{1.8}+5.78\left(\frac{Q}{20,000}\right)^{2} \text { for } C
\end{aligned}
$$

The pressure loss in $C$ Area is less than that in PI and $K$ because of the larger piping in $C$. The constants in these equations were derived by regression analysis. The data for $P$, $L$, and $K$ at cold temperatures (Table 6 ) were anomalous; therefore, they were not used in the correlation. The $(Q / 20,000)^{2}$ term in the above equations correlated from the data is equivalent to the velocity head at the pressure tap plus approximately 0.6 velocity head from turns and valves in the suction piping ( 0.6 velocity head is reasonable for these losses).

Pump Discharge Pressure Tap to Heat Exchanger Discharge Tap. The pressure loss from the pumps through the heat exchangers is correlated by the following equation:

$$
\Delta H_{\mathrm{H}}=482.55(\mu / \rho)^{0.2}\left(\frac{Q}{20,000}\right)^{1.8}+58.16\left(\frac{Q}{40,000}\right)^{2}
$$

This equation is applicable for all areas; minor differences in the piping (length and turns) have an insignificant effect on the over-all losses. The major part of the loss occurs across the heat exchangers that are common in all areas.

Heat Exchanger Discharge Tap to Edge of Reactor Plenum. The loss in the inlet piping to the plenum is related to flow by the following equation:

$$
\Delta H_{I}=132.02(\mu / \mu)^{0.2}\left(\frac{Q P}{20,000}\right)^{1.8}
$$


The $\left(Q_{p} / 20,000\right)^{2}$ term included in the previous equations is not included here because measured data indicated the velocity head recovery at the edge of the plenum was approximately equal to the "square law" losses in the piping turns and the inlet nozzles. Minor differences in the plenum inlet nozzles (between $C$ and PLK) have an insignificant effect on the pressure loss; therefore, the above equation is applicable for all areas.

Plenum Pressure Gradient. The loss in pressure across the reactor plenum was calculated by the following equations:

$$
\Delta H_{P}=\sum_{r=1}^{15} \Delta H_{r}
$$

where

$$
\begin{aligned}
\Delta H_{r} & =4.55(\mu / P)^{0.2}\left(\frac{V_{r}}{10}\right)^{1.8} \\
\Delta H_{P} & =\text { Total loss across reactor plenum, } \mathrm{ft} . \\
\Delta H_{r} & =\text { Head loss across one row of assemblies, ft. } \\
\mu / P & =\text { Kinematic Viscosity, } \mathrm{ft} 2 / \mathrm{sec} \\
V_{r} & =\text { Velocity between rows, of tubes, } \mathrm{ft} / \mathrm{sec}
\end{aligned}
$$

\begin{tabular}{|c|c|c|c|c|c|}
\hline \multirow{2}{*}{\multicolumn{2}{|c|}{ Cycle }} & \multirow{2}{*}{$\begin{array}{l}\text { Plenum } \\
\text { Flow, ggm }\end{array}$} & \multirow{2}{*}{$\begin{array}{c}\text { Temperature, } \\
{ }^{\circ} \mathrm{C} \\
\end{array}$} & \multicolumn{2}{|c|}{ Plenum Head Loss, ft } \\
\hline & & & & Measured & Calculated \\
\hline $\mathrm{C}-6$ & Full Charge & 124,800 & 17 & 23 & 26 \\
\hline P-14 & Fulz Charge & 142,200 & 24 & 30 & 32 \\
\hline$C-1$ & $\begin{array}{l}\text { High Flux } \\
\text { (19 clust,ers) }\end{array}$ & 72,000 & 10 & 73 & 66 \\
\hline$K-13$ & $\begin{array}{l}\text { Curium II } \\
\text { (37 clusters) }\end{array}$ & 126,000 & 25 & 94 & 90 \\
\hline
\end{tabular}

The above equation was derived from the empirical equation presented in Reference 10 for flow across staggered tube banks and results in good agreement with measured data as shown below:

The above equation is simplified for the total plenum pressure loss for full reactor charges (i.e., Mark V-R, VI-E, etc.) and Ciurium II charges ( 37 clusters) as follows: 
January 24, 1967

L. W. Fox

$$
\begin{array}{ll}
\Delta H_{P}=233.13(\mu / \rho)^{0.2}\left(\frac{Q_{P}}{20,000}\right)^{1.8} & \text { Full reactor charge } \\
\Delta H_{P}=810.10(\mu / \rho)^{0.2}\left(\frac{Q_{P}}{20,000}\right)^{1.8} . & \text { Curium II }
\end{array}
$$

DPSP-66-1637

RTR-912

where

$$
Q_{P}=1 / 6 \text { of plenum flow, gpm }
$$

Note: Regular flow zoning arrangements were assumed for these equations.

Comparison of Calculated with Measured Data. Losses in the different segments of the process water system calculated from the above equations are compared to measured data in Figures $6,7,8$ and 9 . The plenum head available calculated from the above equations for each test condition is compared to measured values on Figure 10. The standard error of estimate of the plenum head available for these data is $3.8 \%$, which is equivalent to about $1.6 \%$ in plenum flow.

\section{Septifoil System Hydraulics}

Septifoil system flows are revised as shown on Figure 5 for Pik and C Area using equations for pressure losses in the system developed in Reference 9 from measured data. The total losses in the septifoil piping are summarized as follows:

$$
\Delta \mathrm{H}_{\text {Total }}=\Delta_{\mathrm{Hx}-\mathrm{Hdr}}+\Delta \mathrm{H}_{6^{\prime \prime}}+\Delta_{1 \frac{1}{4}}+\Delta \mathrm{H}+\Delta \mathrm{H}_{\mathrm{O}}+\Delta \mathrm{H}_{\mathrm{s}}
$$

where:

$$
\begin{aligned}
& \Delta H_{\text {Total }}=\text { Total loss in septifoil system piping, } \mathrm{ft} . \\
& \text { (equivalent to heat exchanger discharge pressure) } \\
& \triangle \mathrm{H}_{\mathrm{HX}-\mathrm{Hdr}}=\text { Difference in pressure between heat exchanger discharge } \\
& \text { and septifoil header pressure tap, ft. }=2.46 /\left(\frac{2 \mathrm{~T}}{1000}\right)^{2} \\
& \Delta_{1 \frac{1}{4}} H^{\prime \prime}=\text { Loss in } 1 \frac{1}{2} \text {-inch septifoll supply line; ft. }=27.15\left(\frac{Q_{S}}{100}\right)^{2} \\
& \Delta H=\text { Loss in septifoll supply pin, ft. }=38.85\left(\frac{Q_{S}}{100}\right)^{2}
\end{aligned}
$$


January 24, 1967

L. W. Fox

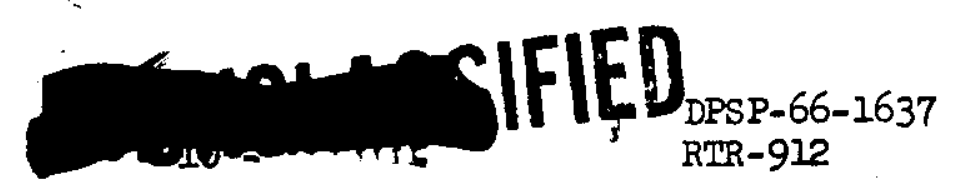

$$
\begin{aligned}
\Delta_{\mathrm{O}}= & \text { Loss across orifice and backup plate, ft }=22.20\left(\frac{Q_{\mathrm{S}}}{100}\right)^{2} \\
& \text { (for Type E ortflce and backup plate) } \\
\Delta_{\mathrm{S}}= & \text { Loss across sheath perforations and slots, ft. }= \\
& 0.87\left(\frac{Q_{\mathrm{S}}}{100}\right)^{2} \text { (for Type J slotted web septifoils) } \\
\mathrm{QT}_{\mathrm{T}}= & \text { Total septifoil flow, Bpm } \\
\mathrm{Q}_{\mathrm{S}}= & \text { Individual septifoil flow, gpm }
\end{aligned}
$$

Note: 73 septifoils in C Area; $Q_{\mathrm{T}}=73 Q_{\mathrm{S}}$

61 sepfitoils in PLIK Areas; $Q_{T}=61 Q_{S}$

Above losses for Type J slotted web septifoils (drawing S4-1-556).

The above equation for septifoil flow was used with the equations developed for losses in the primary system to calculate the plenum head available curves in Figures 11 and 12 and the septifoil flow curves in Figures 13 and 14.

\section{Items Affected by Revised Curves}

The revised head available curves reduce values for process water flow about $5 \%$ from those presently used and alter the specified radial distribution of coolant to the fuel assemblies (relative flows of outer assemblies lower than previously specified). In no case is the effect significant enough to revise any assembly limit. Operating parameters related to flow are slightly affected, such as,

- Pressures within Assemblies

- Channel temperature limits

- Average assembly temperature limits

- BOSF (saturation temperatures)

- Assembly Power

- SIufs power

- BOSF (heat flux)

- Sheath temperatures

- Process water heat balance

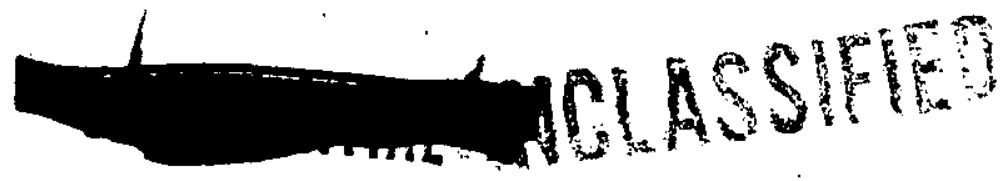


January 24, 1967

I. W. Fox

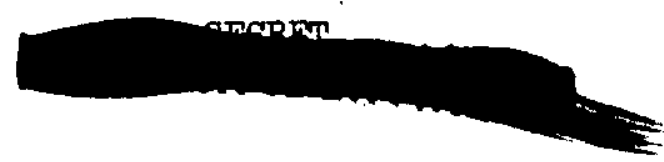

DPSP-66-1637

RTR-912

- Parameters Related to Past Operation

- Relative power distributions

- Flow zoning constants

- Productivity constants

The saturation temperatures at the exit of fuel assembly channels increases with lower specified assembly flows; therefore, operating limits are currently based on flows higher than actually exist and are conservative. The lower flows alter the pressure distribution within the channels and affect the saturation temperature (or BOSF) at different elevations in the assembly.

All parameters based on individual assembly power (i.e., slug power, heat flux, BOSF, etc.) are erroneously high and conservative. ( $5 \%$ flow affects BOSF by $2 \%$ )

The error in flow is largest in assemblies in the outer flow zones; therefore, the real power of these assemblies is less than currentiy specified. With the correct flow distribution, the power fraction of these assemblies can be up to $10 \%$ less than previously indicated; therefore, productivity constants developed from past operation for special irradiations should be revised.

Heat balances between the process water system and cooling water system have generally differed by about $5 \%$ (process system higher); this discrepancy should be resolved by the revised system flows. A comparison of heat balances using flows derived by the old and the revised methods is presented in Table 8; as shown in Table 8 , the anomalies have been essentially eliminated.

Items Not Affected

The values for reactor power are determined from the temperature change and flow of cooling water and are, therefore, not affected by the specified process water flow. Exposure and productivity equations are refined based on 200 Area product separation experience.

The process water flows specified for High Flux charges are not as sensitive to plenum gradients and included correction factors to resolve discrepancies between resistance and Bingham pump data. The specified flows are in agreement with the revised hydraulic information in this report; therefore, the reported maximum neutron flux values achieved during the High Flux charges are considered valid.

Pump cavitation limits and shaft break flow reduction factors, although dependent on process water flows, were determined by reactor tests and related to plenum pressure; therefore, these parameters are not affected by the changes in specified system flows.

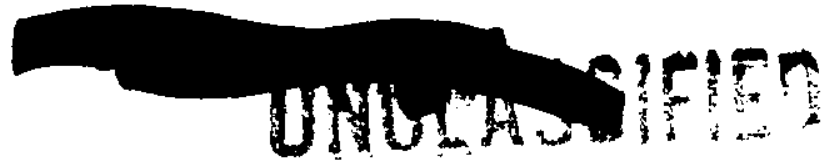


Pump cavitation limits are presented in some reports and operating procedures (i.e., Technical standard) as a function of flow and, therefore, require revising (see Reference 13 for Technical Standard revision). The revision is to eliminate an empirical correction added to force agreement of Bingham data with reactor plenum flows (from extrapolation of test station data) that were determined erroneously.

\section{AC Motor Load Data}

Horsepower measurements at different hydraulic conditions are summarized in Table 7. Motor loads calculated from the new head available curves and the average Bingham pump data are shown for comparison. The $1 \frac{1}{2} \%$ difference (average) between measured and calculated motor loads is reasonable because:

- The measurements are estimated to be accurate to $\pm 1 \%$.

- The variation in average motor loads between each area is about $\pm 0.5 \%$ (from Bingham data).

- The standard error of estimate for flow using the revised head available curves is $1.6 \%$ (equivalent to $\pm 0.6 \%$ in motor load).

The measured data normalized to operating conditions are plotted on Figure 14.

The loading on theAC motors is the Bingham pump brake horsepower plus

- the energy dissipated in the gear reduced (approximately $45 \mathrm{hp}$ ) minus the horsepower delivered by the DC motors ( $75 \mathrm{hp}$ at $1800 \mathrm{rpm}$ ).

The pump brake horsepower can be calculated from data presented in Tables, 1 , $2,3,4$, and 5 by the following equation:

$$
\mathrm{bhp}=\frac{\mathrm{QH} \rho}{\mathrm{E}(7.481)(33,000)}
$$

where:

$$
\begin{aligned}
\text { bhp } & =\text { Pump brake horsepower } \\
Q & =\text { Pump flow, gpm } \\
H & =\text { Total dynamic head, ft } \\
E & =\text { Pump efficiency } \\
P & =\text { Fluid density, } l \mathrm{~b} / \mathrm{ft}^{3}
\end{aligned}
$$

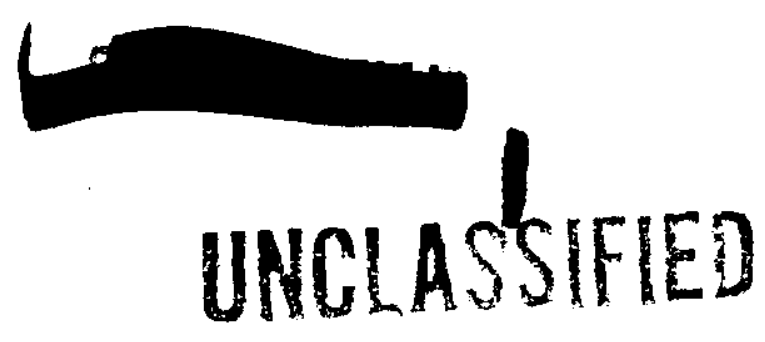


A Ioading of $3400 \mathrm{hp}$ was recommended by the Engineering Department (Reference jo) for the $A C$ motors during normal operation although temporary overloads to $3450 \mathrm{hp}$ were considered acceptable. Process water flows for each area which correspond to the 3400 rating are presented in Reference 14; however, these flows are based on the incorrect plenum head avaijeble curves and limited data for each area.

An analysis of the variation in flows, extrapolated from measured data in Table 7 and normalized to operating conditions (see Figure 16), corresponding to the 3400 rating indicate the small aifferences between areas reported previously (Reference 14 ) are inherent in specific motors, small fiow differences, and small measurement uncertainties. Reactor llows corresponding to the $3400 \mathrm{hp}$ rating are sumarized below; additional data will be taken (especially in $\mathrm{KC}$ ) to improve the extrapolations.

Reactor Flows Corresponding to AC Motor Iosd or 3400 hp

$\begin{array}{ll}\text { Reactor } & \text { Standerd } \\ \text { System } & \text { Deviation } \\ \text { Flow, gpm* } & \text { gpm EP }\end{array}$

Measured Data

- Maximum Motor at 3400

$154,000 \quad 7,300 \quad 45$

- Average Hotor at 3400 or Maximum Motor at $3450 \quad 162,600 \quad 6,800 \quad 40$

Calculated From Bingham Data**

- Average Motor at 3400

167,000

* Average flows extrapolated from data for all areas.

* Calculated from average data for Bingham pumps and revised head available curves.

$C A B: g r b$

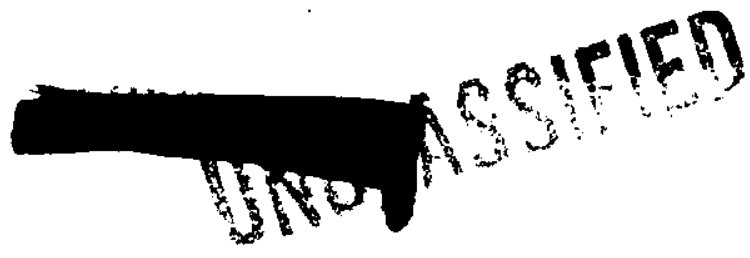


January 24,1967

1. Paulson, W. A., to F. E. Kruesi, "Bases for Flow Zoning SRP Reactor Charges", RIR 325, DPSP 61-2133, Twne 6, i962 (Secret).

2. BPF 209325, "Total. Dynamic Head Curves for Bingham Punpos".

3. Field, F. R., to A. A. Johnson, "Hydraulic Test Data - C-6", RTR-39, DPSP 57-662, April 4, 1957 (Secret).

4. Gimmy, K. I., to A. A. Johnson, "Process Water Test Data. - K Area"?, RTE-50, DESE ? 12142, August 23, 1957 (Secret).

5. Gimny, K, I, to $A$. A. Johnson, "Bingham Startup Test Data - P and R", RriR-144, DESP 59-794, Apri1 17, 1959 (Secret).

6. WTD Monthily Fogress Report for August, 1966, DPSP 66-1-8, p 1.18 (secret).

7. TA 1-1577, "Pressure-Tap Upper Plugs"; DPSOX 6597, August 19, 1966 (Unclassified).

8. Bland, C. A., "Process System Hydraulic Calculations", DPSP 66-972, December 14, 1966 (Secret).

9. Bland, C. A. and J. M. Morrison, "Septifoil Calculations Notebook", DPSPU 66-138, December 14, 1966.

10. Perry, Joinn H., Chemical Engineers: Handbook, Fourth Eäition, McCraw-Hill, New York (1963),pp 5-47.

11. Singleton, F. D. and J. B. Tinker, letter to D. A. Miller and G. B Carlton, "3400 HP AC Motors Driving Bingham Pumps", November 9, 1956.

12. Temple, C. J., to F. E. Kruesi, "Shaft Break Flow Reductions", RTR 294, DPSP 60-3286, March 10, 1961 (Secret).

13. Bland, C. A., "Savannah River Plant Technical Standard Revision Proposel - Heavy Weter Temperatures", DPSP 66-1675, January 16, 1967 (Secret).

14. WID Monthly Progress Report for May 1966, DPSP 66-1-5, p 133 (Secret).

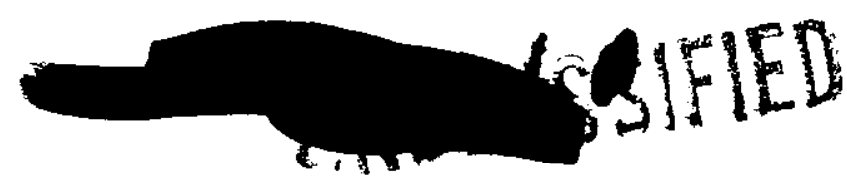




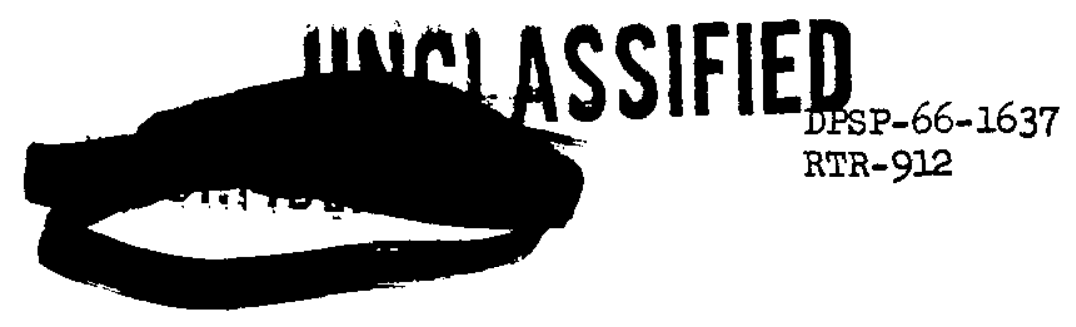

Table 1

Bingham Pump Data - P Area

\begin{tabular}{|c|c|c|c|c|c|c|c|c|c|c|c|c|}
\hline \multirow{3}{*}{$\begin{array}{l}\text { System } \\
\text { Pump } \\
\text { Serial } \\
\text { \#31799 - } \\
\text { Flow, gm }\end{array}$} & \multicolumn{2}{|c|}{1} & \multicolumn{2}{|c|}{2} & \multicolumn{2}{|c|}{$=$} & \multicolumn{2}{|c|}{4} & \multicolumn{2}{|l|}{5} & \multicolumn{2}{|l|}{6} \\
\hline & 23 & & 20 & & 22 & & $2]$ & & 24 & & 25 & \\
\hline & $T D H$ & $E$ & $\mathrm{TDH}$ & $\mathrm{E}$ & TDH & $E$ & TDH & $\mathrm{E}$ & $\underline{\mathrm{TDH}}$ & $\mathrm{E}$ & $\underline{T D H}$ & $E$ \\
\hline 0 & 566.5 & - & 562.7 & - & 568.9 & - & 566.5 & - & 565.5 & - & 47.4 & - \\
\hline 6,000 & 538.9 & 45.0 & 536.6 & 45.6 & 538.9 & 45.1 & 538.9 & 45.0 & 535.9 & 44.9 & 533.4 & 45.4 \\
\hline 10,000 & 523.4 & 64.1 & 523.1 & 65.2 & 527.8 & 63.4 & 523.4 & 64.1 & 524.2 & 65.2 & 520.5 & 63. \\
\hline 14,000 & 510.2 & 76.0 & 09.5 & 76 & 5 & 76.1 . & 510.2 & 76.0 & 508.8 & 76.3 & 506.2 & 75. \\
\hline 18, & 488.6 & 83.2 & 487.9 & 83.9 & 492.7 & 83.9 & 488.6 & 83.2 & 487.6 & 84.0 & 484.2 & 83. \\
\hline 22,000 & 457.8 & 86.8 & 456.7 & 87.5 & 458.0 & 86.9 & 457.8 & 86.8 & 455.3 & 87.4 & 451.7 & 86. \\
\hline 25,000 & 429.9 & 87.7 & 427.1 & 87.8 & 429.5 & 87.6 & 429.9 & 87.7 & 427.0 & 88.1 & 424.0 & 87. \\
\hline 28,000 & 393.1 & 86.6 & 390.6 & 86.8 & 392.1 & 86.6 & 393.1 & 86.6 & 390.9 & 86.8 & 385.0 & 86. \\
\hline, 000 & 365.2 & 84.4 & 360.2 & 84.2 & 362.5 & 83.8 & 365.2 & 84.4 & 361.9 & 84.8 & 353.5 & 83. \\
\hline
\end{tabular}


January 24, 1967

\section{UNCLASSIFIED}

DPSP-66-1637

RIR-912

Table 2

Bingham Purmp Data - I Area

System

Pump

Serial \#31799- 14

Flow, gpm

0

6,000

10,000

14,000

18,000

22,000

25,000

28,000

30,000

556.3

455.6 426.7

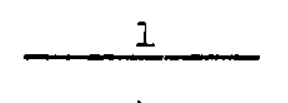

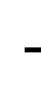

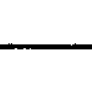

17

2

TDH $\mathrm{E}$ TDH

$568.2-567.7$ -

568.2

$535.01+5.8$

$540.7 \quad 46.3$

$524 . ; 64$.

$527.5 \quad 64.2$

$541.2 \quad 45.4$

529.264 .8

$\begin{array}{llllll}511.1 & 75.8 & 513.7 & 76.1 & 514.1 & 76.1\end{array}$

$486.9 \quad 83.9 \quad 491.9$

83.6492.

85.4

457.1

86.9

461.

83.6
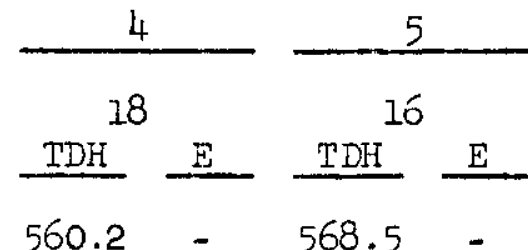

TDH

568.5

$537.6 \quad 44.7$

543.1

524.862 .2

531.3

510.175 .5

516.3

$\begin{array}{llllll}87.0 & 82.2 & 493.5 & 84.1 & 488.1 & 83.3\end{array}$ 


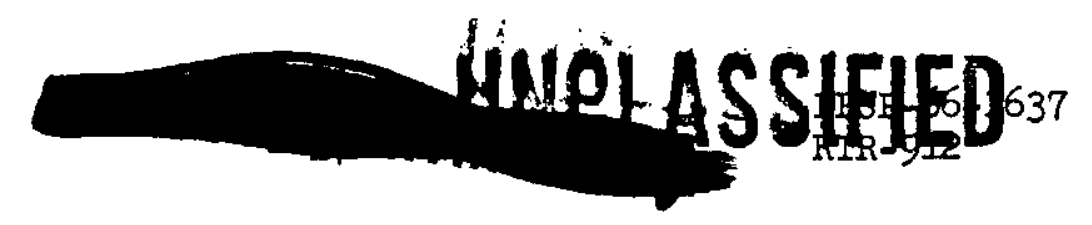

Table 3

Bingham Pump Data - K Area

\begin{tabular}{|c|c|c|c|c|c|c|c|c|c|c|c|c|}
\hline \multirow{3}{*}{$\begin{array}{l}\text { System } \\
\text { Pump } \\
\text { Serial } \\
\text { \#31799- } \\
\text { Flow, gpm }\end{array}$} & \multicolumn{2}{|c|}{1} & \multicolumn{2}{|c|}{2} & \multicolumn{2}{|c|}{3} & \multicolumn{2}{|c|}{4} & \multicolumn{2}{|c|}{ 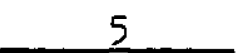 } & \multicolumn{2}{|c|}{6} \\
\hline & 12 & & 13 & & 10 & & 9 & & 8 & & 11 & \\
\hline & TDH & $E$ & TDH & $E$ & TDH & $E$ & $\mathrm{TDH}$ & $E$ & TDH & $E$ & $\mathrm{TDH}$ & $E$ \\
\hline 0 & 552.4 & - & 552.3 & - & 566.6 & - & 564.3 & - & 565.5 & - & 557.4 & - \\
\hline 6,000 & 535.6 & 46.4 & 539.1 & 46.1 & 538.4 & 45.6 & 538.6 & 46.2 & 538.8 & 45.4 & 539.8 & 45.2 \\
\hline 10,000 & 524.9 & 65.1 & 527.4 & 65.2 & 528.9 & 65.0 & 529.3 & 65.5 & 526.5 & 64.7 & 528.2 & 64.8 \\
\hline 14,000 & 508.9 & 77.1 & 512.7 & 76.8 & 513.3 & 75.8 & 512.1 & 76.3 & 511.3 & 76.1 & 513.8 & 76.1 \\
\hline 18,000 & 487.1 & 83.9 & 492.4 & 84.1 & 488.9 & 82.7 & 491.9 & 83.8 & 491.0 & 83.3 & 494.5 & 83.7 \\
\hline 22,000 & 453.8 & 86.8 & 456.9 & 86.6 & 453.4 & 85.9 & 457.2 & 86.8 & 4597.6 & 86.5 & 462.6 & 86.6 \\
\hline 25,000 & 422.5 & 87.4 & 425.5 & 87.5 & 423.8 & 86.4 & 426.4 & 87.3 & 426.0 & 87.0 & 432.7 & 87.4 \\
\hline 28,000 & 387.3 & 86.2 & 387.7 & 85.8 & 388.4 & 85.9 & 389.5 & 85.9 & 390.4 & 85.9 & 398.8 & 86.4 \\
\hline 30,000 & 359.7 & 84.9 & 359.1 & 83.7 & 356.0 & 82.8 & 358.4 & 83.1 & 361.4 & 83.6 & 370.3 & 84.6 \\
\hline
\end{tabular}


Table 4

\section{Bingham Pump Data - C Area* - Original Impellers}

\begin{tabular}{|c|c|c|c|c|c|c|c|c|c|c|c|c|}
\hline \multirow{3}{*}{$\begin{array}{l}\text { System } \\
\text { Pump } \\
\text { Serial } \\
\text { \#31799- } \\
\text { Flow, gpm }\end{array}$} & \multicolumn{2}{|c|}{ 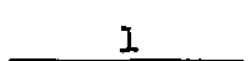 } & \multicolumn{2}{|c|}{ ? } & \multicolumn{2}{|c|}{2} & \multicolumn{2}{|c|}{4} & \multicolumn{2}{|c|}{5} & \multicolumn{2}{|c|}{6} \\
\hline & \multicolumn{2}{|c|}{7} & \multicolumn{2}{|c|}{2} & \multicolumn{2}{|c|}{3} & \multicolumn{2}{|c|}{4} & \multicolumn{2}{|c|}{5} & \multicolumn{2}{|c|}{6} \\
\hline & $\mathrm{TDH}$ & E & $\mathrm{TDH}$ & $E$ & $\mathrm{TDH}$ & $\underline{E}$ & TDH & $E$ & TDH & $E$ & $\mathrm{TDH}$ & $E$ \\
\hline 0 & 565.1 & - & 559.7 & - & 551.2 & - & 548.1 & - & 558.2 & - & 562.2 & - \\
\hline 6,000 & 535.6 & 45.8 & 539.2 & 46.4 & 532.3 & 45.7 & 539.2 & 46.2 & 536.8 & 46.3 & 534.0 & 45.7 \\
\hline 10,000 & 523.7 & 65.1 & 528.9 & 65.3 & 523.2 & 62.9 & 528.4 & 65.3 & 525.6 & 65.0 & 521.2 & 65.2 \\
\hline 14,000 & 509.1 & 76.1 & 516.5 & 76.6 & 508.9 & 75.8 & 514.1 & 76.8 & 507.6 & 76.7 & 508.2 & 76.0 \\
\hline 18,000 & 486.6 & 84.0 & 490.4 & 83.8 & 488.6 & 84.2 & 493.3 & 84.2 & 487.9 & 84.4 & 487.7 & 84.0 \\
\hline 22,000 & 453.7 & 87.2 & 455.8 & 86.8 & 455.9 & 87.7 & 459.8 & 87.0 & 454.8 & 87.1 & 452.6 & 86.4 \\
\hline 25,000 & 422.0 & 87.2 & 423.3 & 86.7 & 424.3 & 87.7 & 431.0 & 88.2 & 423.4 & 87.5 & 421.2 & 86.7 \\
\hline 28,000 & 383.6 & 86.1 & 388.7 & 86.3 & 388.1 & 86.8 & 395.6 & 86.9 & 387.7 & 86.4 & 385.0 & 85.8 \\
\hline 30,000 & 356.3 & 83.8 & 360.5 & 84.3 & 361.0 & 84.7 & 367.3 & 85.0 & 359.3 & 84.1 & 355.0 & 83.3 \\
\hline
\end{tabular}

* The impelzers originaj.Iy in the C Area pumps were replaced with the impellers from $R$ Area pumps following the High Flux program in 1966 because of excessive cavitation damage in the eye of the impeller.

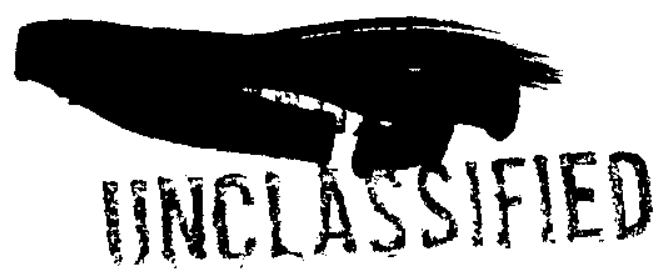


January 24, $1967^{\circ}$

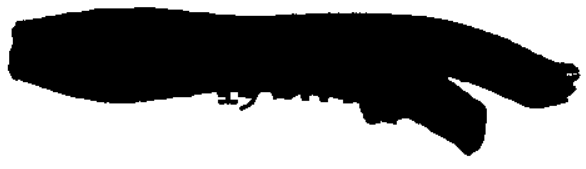

DPSP-66-1637

RTR-912

Table 5

Bingham Pump Data - Average of All Pumps

\begin{tabular}{|c|c|c|c|}
\hline $\begin{array}{l}\text { System } \\
\text { Flow, gpm }\end{array}$ & $\begin{array}{l}\text { Totel Dymamic } \\
\text { Head, ft }\end{array}$ & $\begin{array}{c}\text { Pump } \\
\text { Efficiency, } \%\end{array}$ & \\
\hline 0 & 561.05 & - & 28.5 \\
\hline 6,000 & 537.80 & 45.60 & 75,3 \\
\hline 10,000 & 525.98 & 64.35 & \\
\hline 24,000 & 511.20 & 76.18 & \\
\hline 18,000 & 489.58 & 83.70 & \\
\hline 22,000 & 456.23 & 86.79 & \\
\hline 25,000 & 426.15 & 87.44 & \\
\hline 28,000 & 389.83 & 86.29 & \\
\hline 30,000 & 360.60 & 84.02 & \\
\hline
\end{tabular}

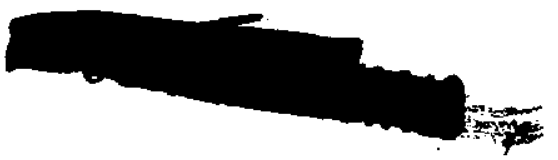



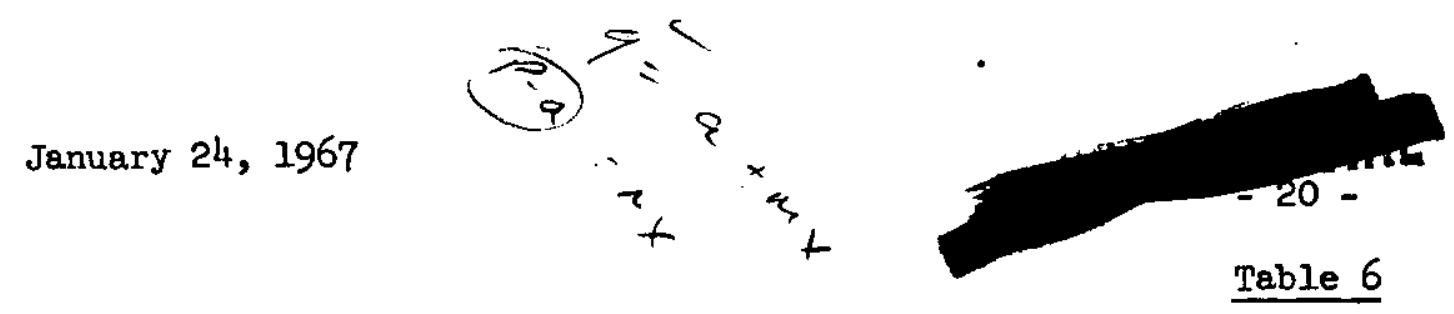

DPSP-66-1637

RTR-912

Process Water System Data*

\begin{tabular}{|c|c|c|c|c|c|c|c|c|c|c|c|c|}
\hline \multirow[b]{2}{*}{ Cyclé } & \multirow{2}{*}{$\begin{array}{l}\text { Type } \\
\text { Charge } \\
\end{array}$} & \multicolumn{3}{|c|}{ Pump } & \multirow{2}{*}{$\begin{array}{l}\text { Pump Suction } \\
\text { Loss, } \triangle \mathrm{H}_{\mathrm{S}} \text {. }\end{array}$} & \multicolumn{3}{|c|}{ Heat Exchanger } & \multicolumn{3}{|c|}{ Plenum \& Inlet } & \multirow{2}{*}{$\begin{array}{l}\text { Plenum** } \\
\text { Head }\end{array}$} \\
\hline & & $\triangle \mathrm{H}$ & Flow & Temp & & $\triangle \mathrm{H}_{\mathrm{H}}$ & Flow & Ternpt & $\overline{\Delta H_{L}+\Delta H_{P}}$ & Flow & Temp & \\
\hline$R-1$ & Mark VII-A & 418.7 , & 23,400 & 28.0 & 14.5 & 141.7 & 23,400 & 28.0 & 48.6 & 23,400 & 28.0 & $214.0^{\prime}$ \\
\hline$R-1$ & Mark VII-A & 412.9 & 23,900 & 30.0 & 15.3 & 146.0 & 23,900 & 30.0 & 47.7 & 22,763 & 30.0 & 203.9 \\
\hline P-14 & Mark VII-A & 41.53 & 23,700 & 24.0 & 14.4 & 141.3 & 23,700 & 24.0 & 50.6 & 23,700 & 24.0 & 209.1 \\
\hline$p-14$ & Mark VII-A & 410.6 & 24,150 & 24.0 & 15.6 & 146.9 & 24,150 & 24.0 & 48.5 & 22,963 & 24.0 & 19 \\
\hline $5-11$ & Mark VI & 447.3 & 20,800 & 24.0 & 12.6 & 112.8 & 20,000 & 24.0 & 41.1 & 20,800 & 24.0 & \\
\hline K-ג & Mark VI & 440.5 & 21,500 & 24.0 & 13.5 & 121.1 & 21,500 & 24.0 & 35.5 & 20,172 & 24.0 & \\
\hline-6 & Mark VI & 448.2 & 20,800 & 17.0 & 7.8 & 125.7 & 20,800 & 17.0 & 34.7 & 20,800 & 17.0 & \\
\hline$c-6$ & 'Wark VI & 439.9 & 21,500 & 17.0 & 8.5 & 130.1 & 21,500 & 17.0 & 36.3 & 20,150 & $17.0^{\circ}$ & \\
\hline P-9 & Mark V-R & 400.7 & 24,900 & 92.3 & 14.4 & 155.1 & 24,507 & $67 \cdot 3$ & $43.3^{\circ}$ & 23,135 & 42.2 & 100 \\
\hline-6 & Mark VI-E & 398.9 & 25,100 & 91.6 & 14.4 & 146.6 & 24,704 & 66.4 & 34.9 & 23,314 & 41.4 & 195 \\
\hline $\mathrm{K}-14$ & Mark XII & 433.4 & 22,200 & 75.3 & 11.5 & 126.8 & 21,956 & 54.4 & 108.9 & 20,528 & 33.5 & 181.3 \\
\hline$c-4$ & Mark V-B & 393.4 & 25,300 & 94.1 & 10.9 & 152.5 & 24,860 & 67.1 & 46.9 & 23,838 & 40.1 & 175.3 \\
\hline C-10 & Curium I & 375.3 & 26,850 & 81.0 & 12.6 & 170.0 & 26,514 & 59.5 & 52.3 & 25,142 & 37.9 & 148.0 \\
\hline
\end{tabular}

* All flows and losses $(\triangle H)$ are in gpm and feet, respectively, at temperature $\left({ }^{\circ} \mathrm{C}\right.$ ) of fluid; system flows were determined from pump $\mathrm{H}$ curve ( $\mathrm{Table}$ 5). System pressures were measured with Heise gages.

** Measured head at center of plenum at Zero elevation (excluding blanket gas, pressure).

+ Average temperature of heat exchanger flow is average of reactor effleunt and plenum inlet. 
7. Summary of AC Motor Load Measurements

$\begin{array}{lllllllllll}\text { j-2 } & \text { K-1I } & \text { K-I4 } & \text { K-1l } & \text { K-11 } & \text { C-6 } & \text { C-10 } & \text { C-11 } & \text { C-21 } & \text { C-2 } \\ \text { :k VI-B } & \text { Mark VI } & \text { Mark V-B } & \text { Mark XII } & \text { Mark XII } & \text { Mark VI } & \text { Cm-I } & \text { Cm-I } & \text { Hi } \varnothing & \text { Mark V-B } \\ 129 / 65 & 7 /-/ 57 & 11 / 19 / 65 & 7 / 29 / 66 & 8 / 3 / 66 & 2 /-/ 57 & 9 / 14 / 64 & 9 / 30 / 64 & 11 / 23 / 65 & 5 / 5 / 66 \\ \text { L.2 } & 271.9 & 184.3 & 196.0 & 188.0 & 265.0 & 148.0 & 162.2 & 382.3 & 174.8 \\ .960 & 21,500 & 24,860 & 22,230 & 22,400 & 21,500 & 26,090 & 25.760 & 14,220 & 25,330 \\ .2 & 24.0 & 90.0 & 25.0 & 72.7 & 17.0 & 81.0 & 90.6 & 72.0 & 89.0\end{array}$

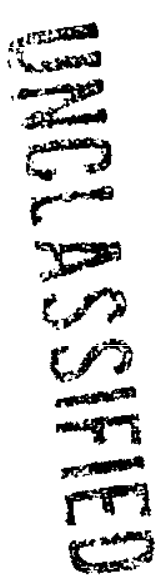

\begin{tabular}{|c|c|c|c|c|c|c|c|c|c|}
\hline (2) & (1) & (2) & (2) & (2) & (1) & (1) & (1) & (2) & (2) \\
\hline 3256 & 3000 & 3270 & 3184 & 3170 & 3100 & 3333 & 3280 & 2412 & \\
\hline 3245 & $3042^{x}$ & 3270 & 3159 & 3147 & 3205 & 3334 & 3290 & $2497^{x}$ & \\
\hline 3245 & 3021 & 3245 & 3184 & 3170 & 3126 & 3356 & 3320 & 2460 & \\
\hline 3256 & 3011 & 3319 & 3232 & 3221 & $3231^{x}$ & $3446^{x}$ & $3400^{x}$ & 2484 & \\
\hline 3240 & 3021 & 3277 & 3154 & 3154 & 3061 & 3382 & 3271 & 2412 & \\
\hline $3277^{x}$ & 3032 & $3362^{x}$ & $3240^{x}$ & 3232 & 3139 & 3374 & 3333 & 2473 & \\
\hline 3253 & 3021 & 3290 & 3192 & 3182 & 3144 & 3371 & 3316 & 2456 & 3221 \\
\hline 3175 & 3137 & 3226 & 3182 & 3164 & 3140 & 3294 & 3262 & 2534 & 3282 \\
\hline
\end{tabular}

ite method of measurement: (1) 151 Building watt-hr meter (2) Weston precision Test dd Temp Conditions; $75 \mathrm{hp}$ from DC motors and $45 \mathrm{hp}$ dissipated in gear reducer. 


\section{UNCLASSIFIED

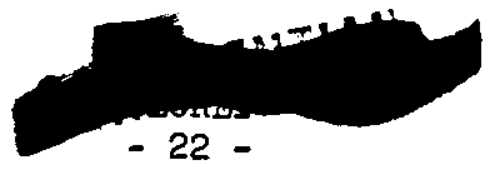 \\ DPSP-66-1637 \\ RTR-912}

Table 8

Reactor System Heat Balance Data

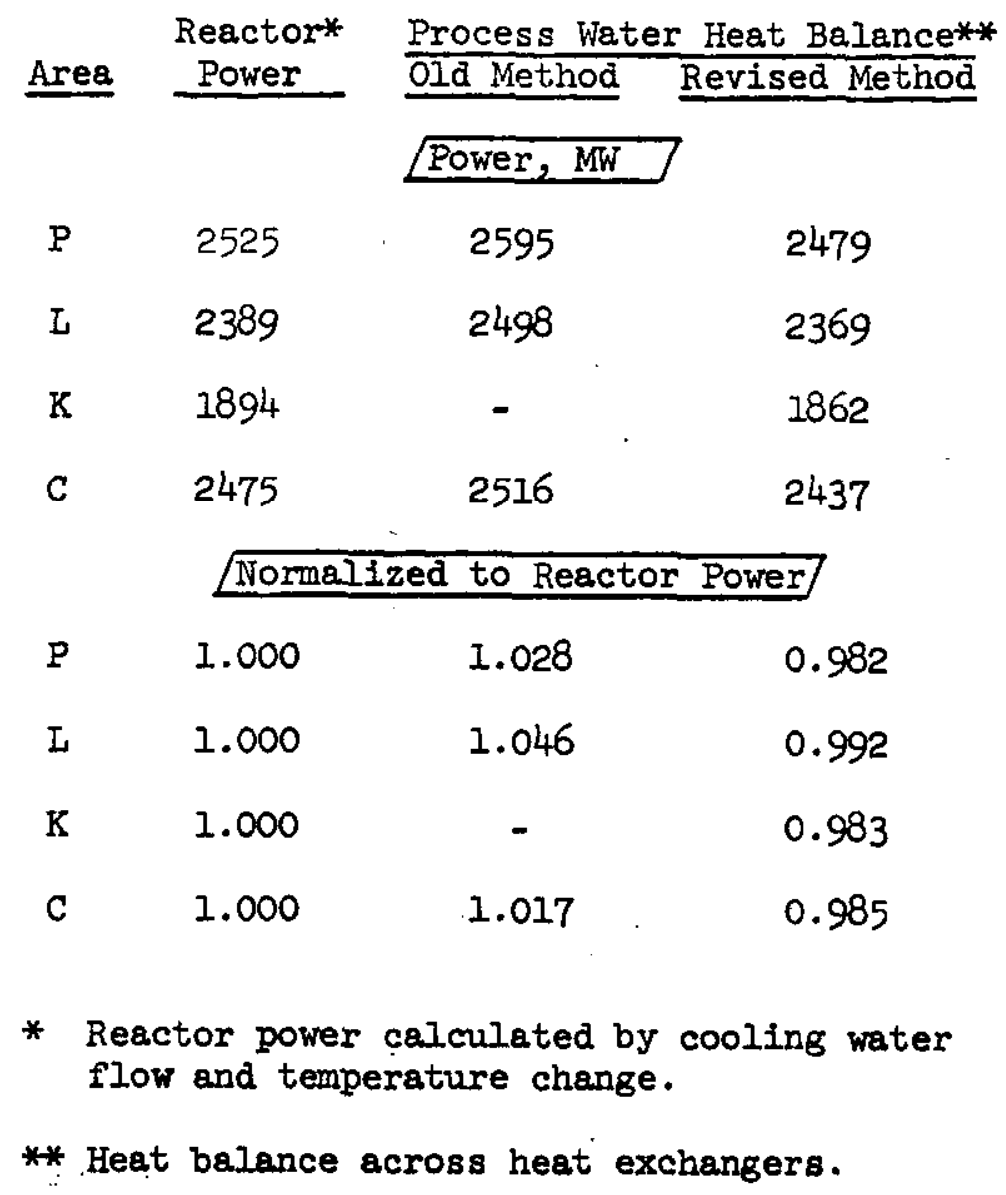

UNCLASSIFIED

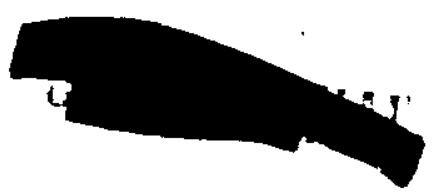




\section{UNCLASSIFIEO \\ DPSP-66- 1637 \\ RTR-912}

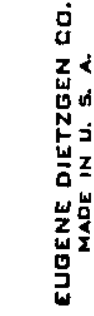

c
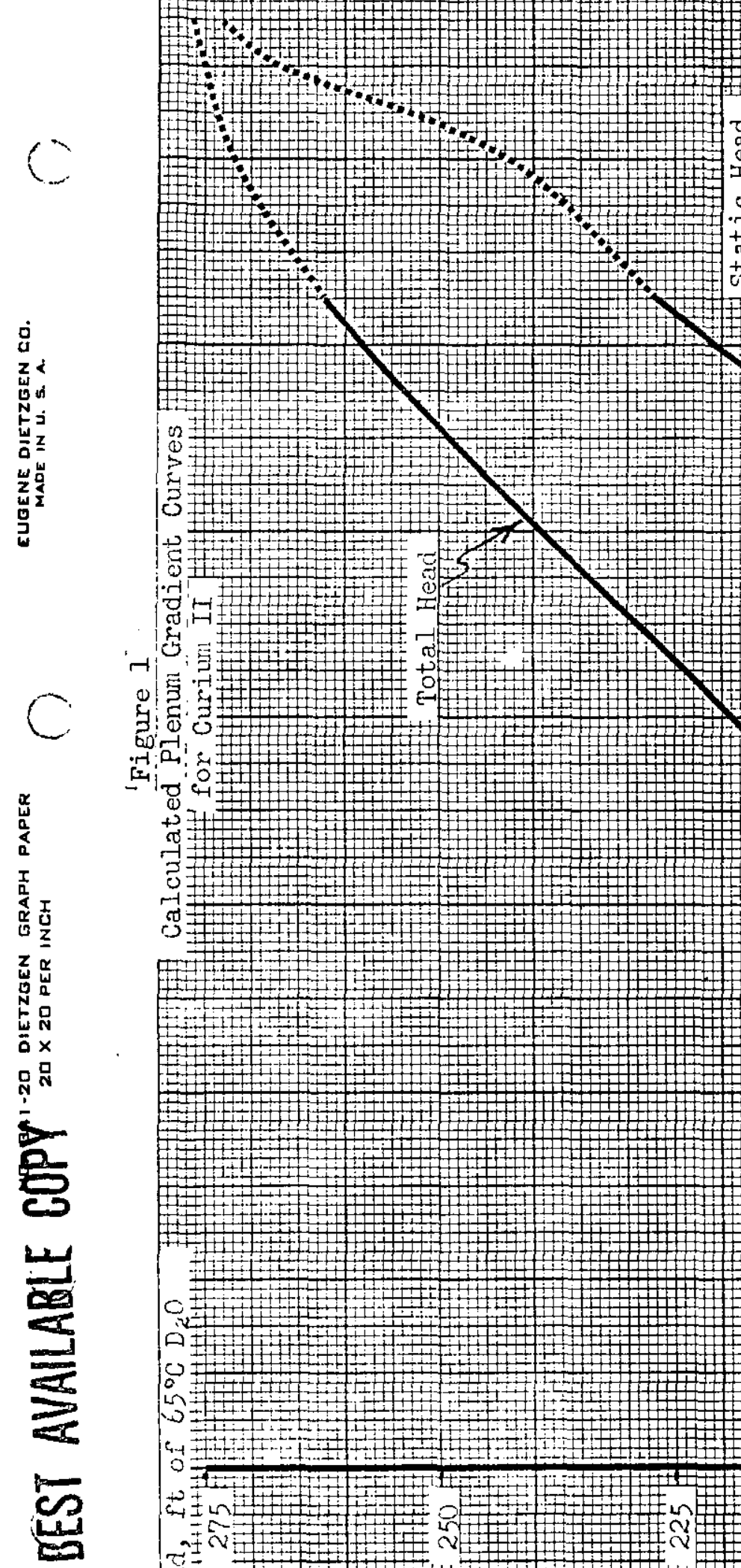

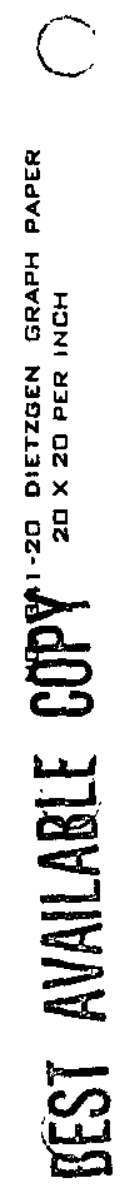

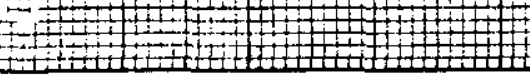
"WCLASSTED 


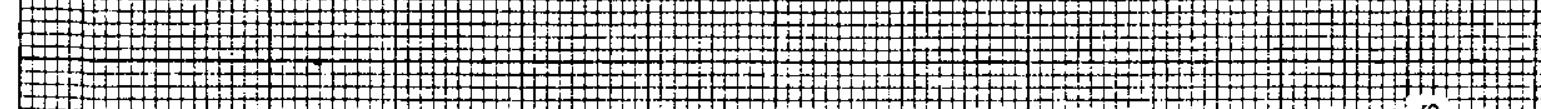

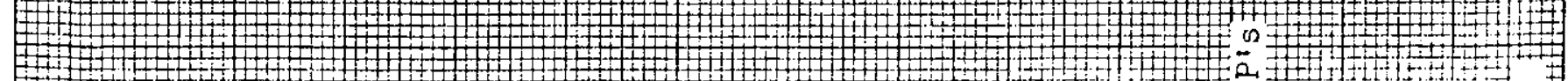
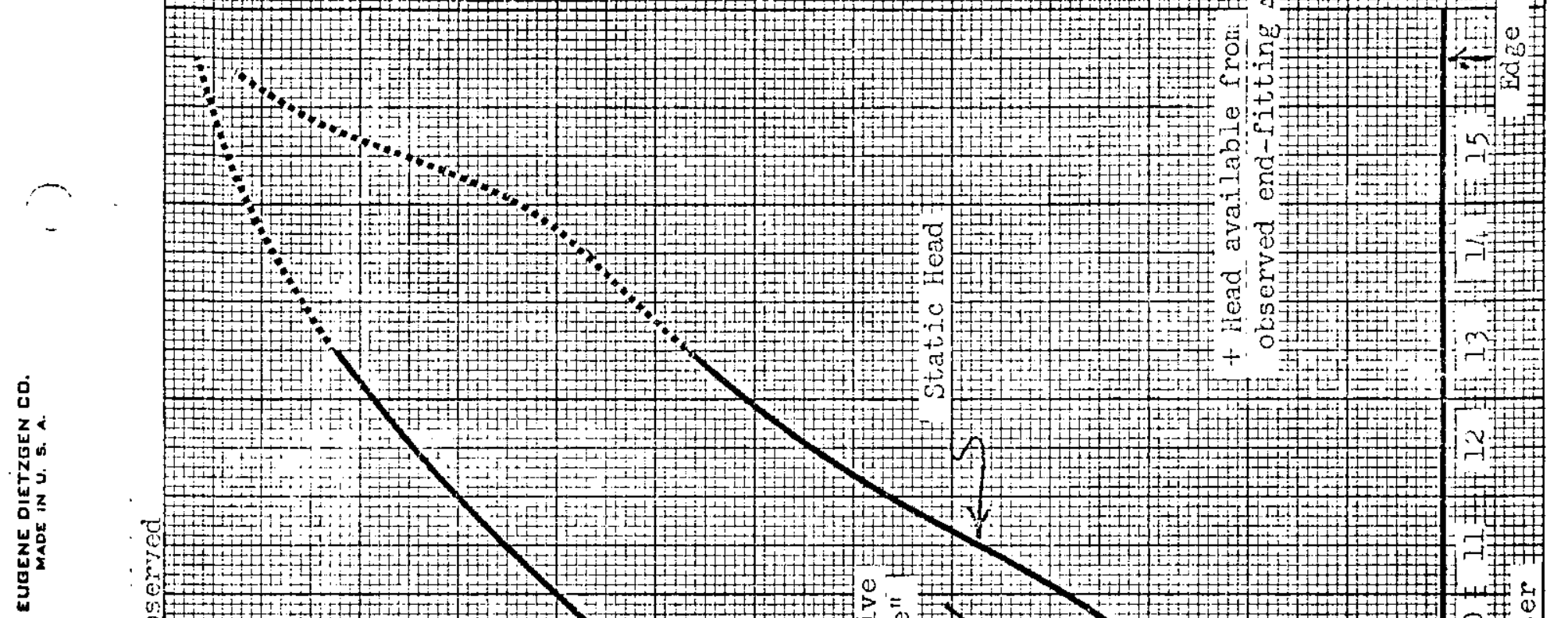

$\bigcup_{\substack{6 \\ 0}}^{\infty}$

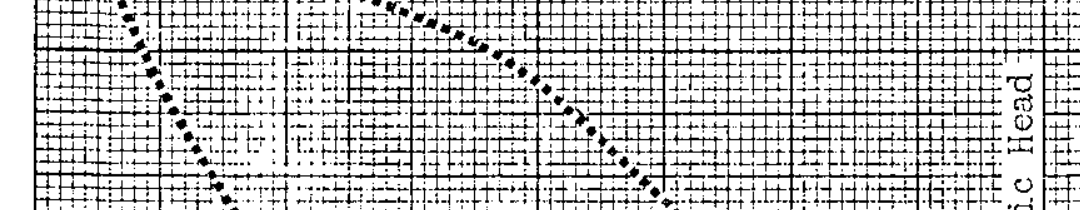

P

.

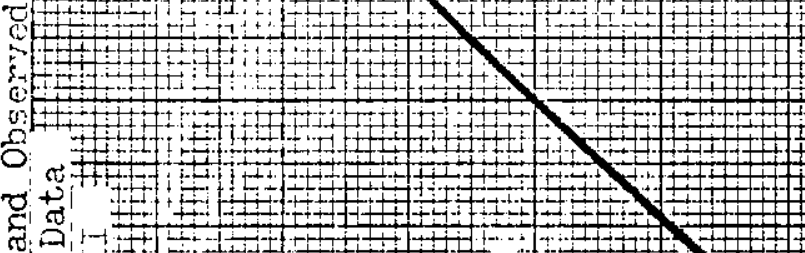

.
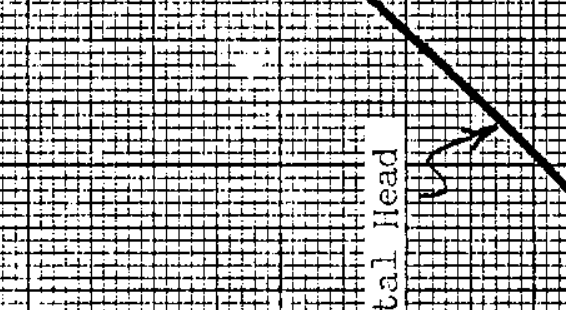

$4+11$
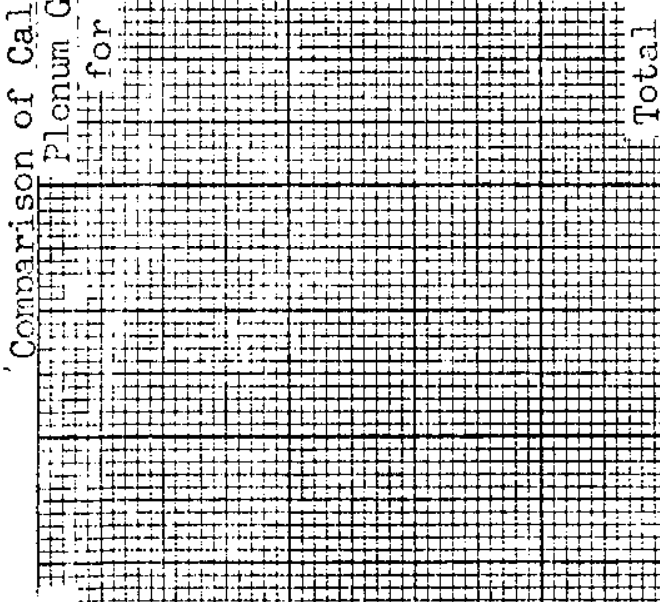
Figure 3

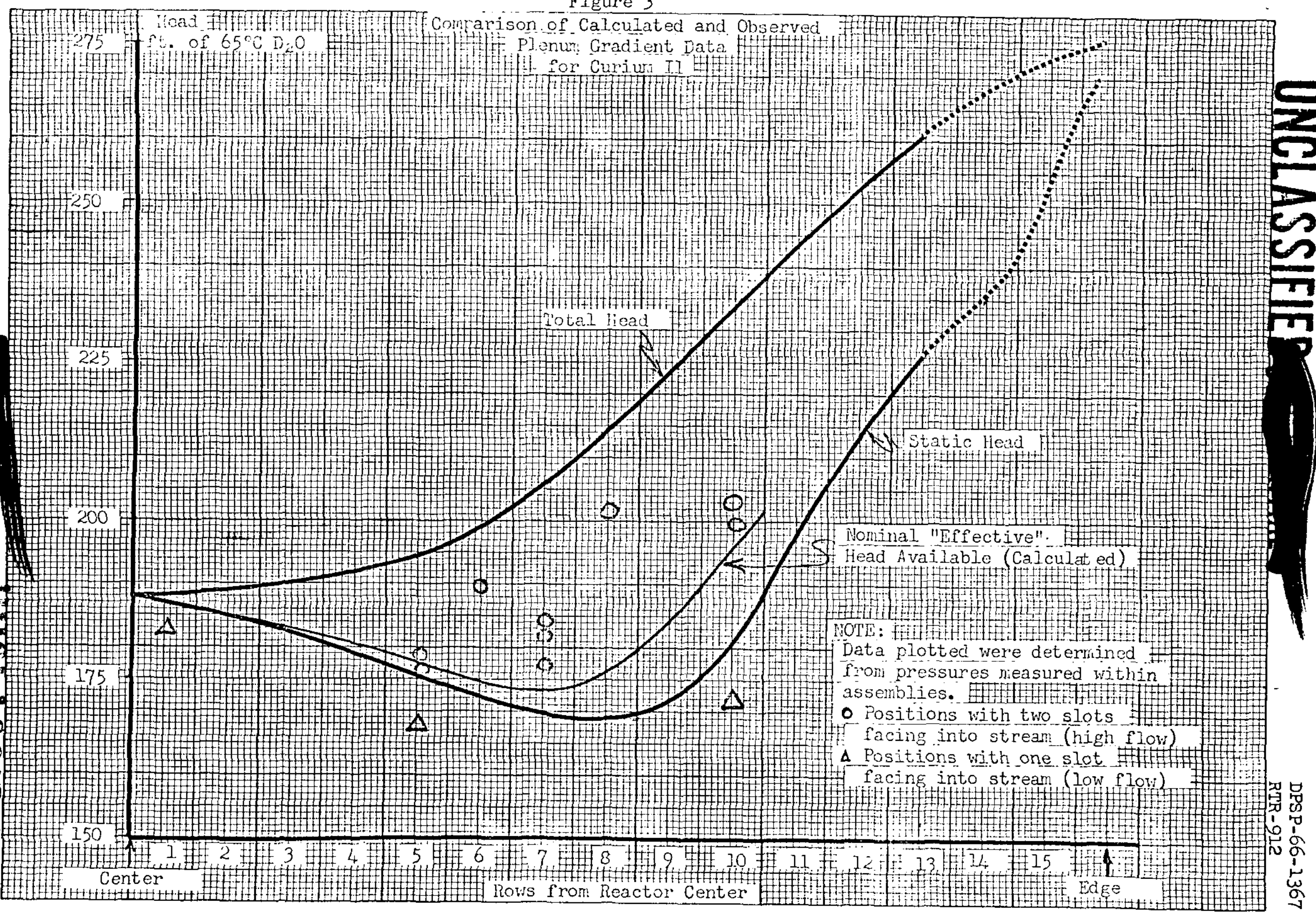




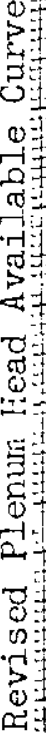
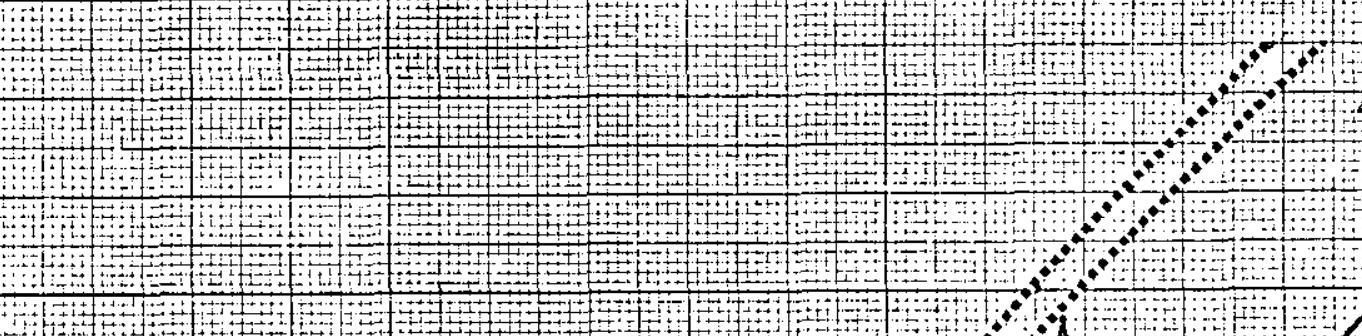
Figure 5

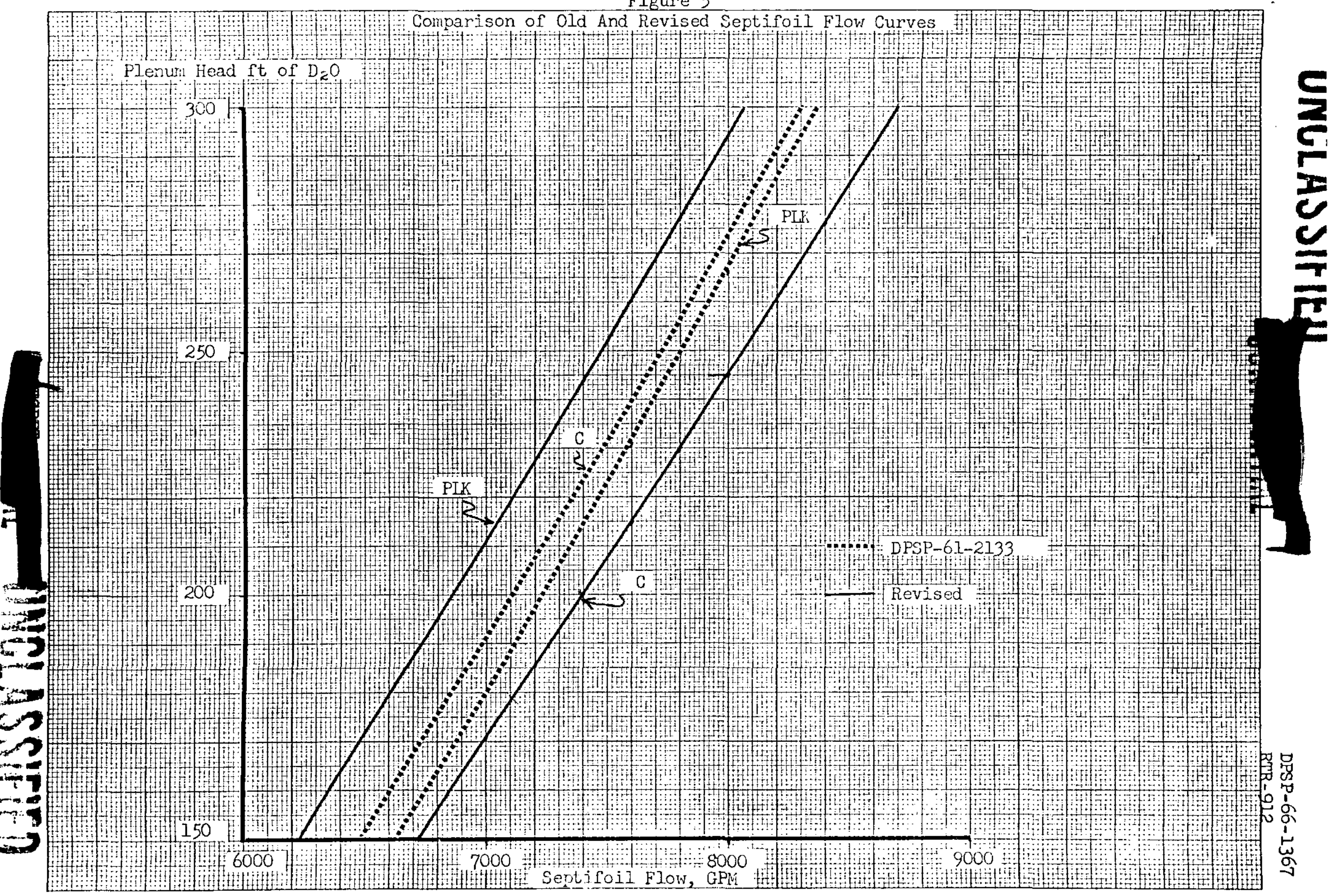


Figure 6

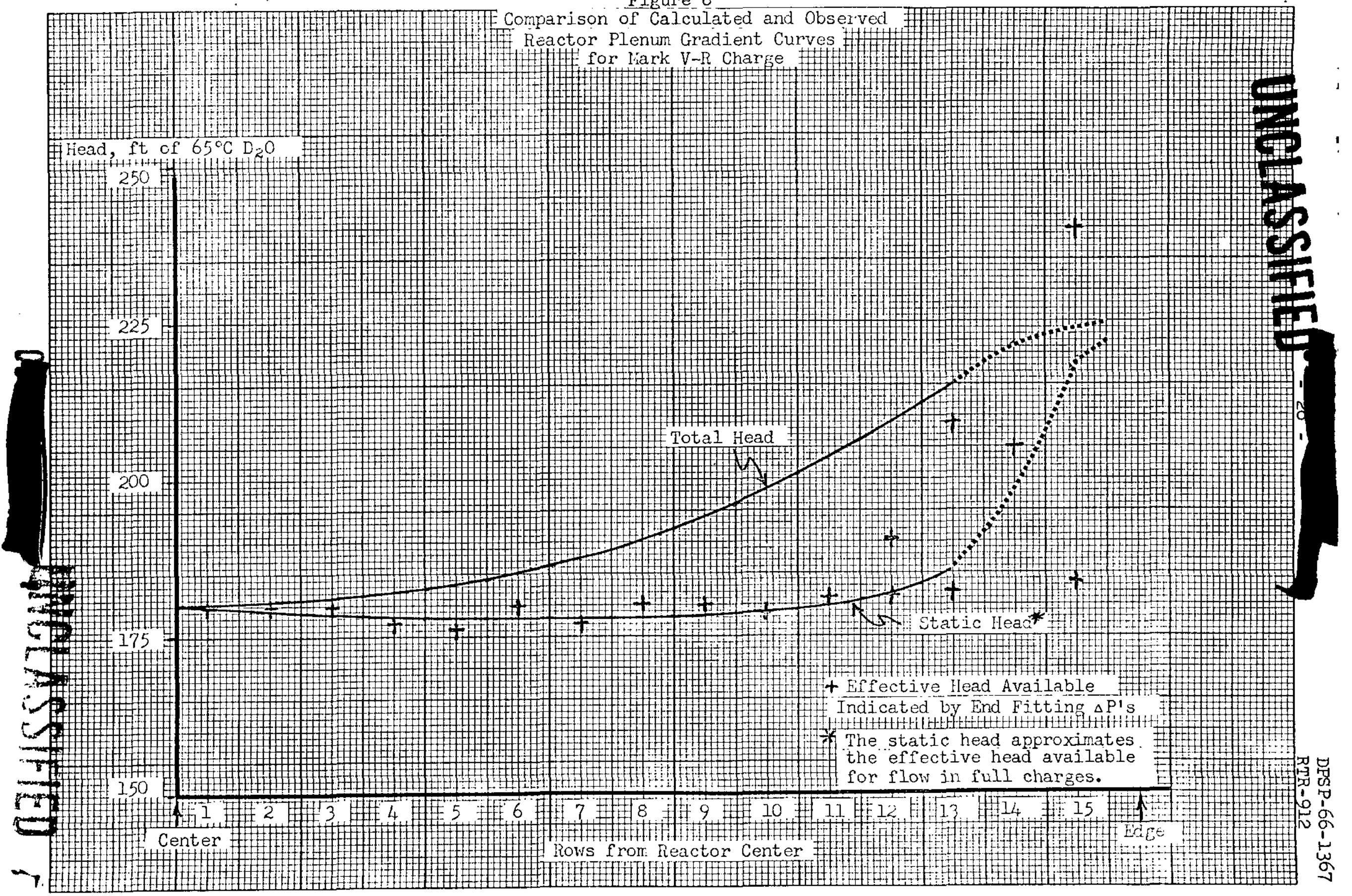




\section{UNCLASSIFY:

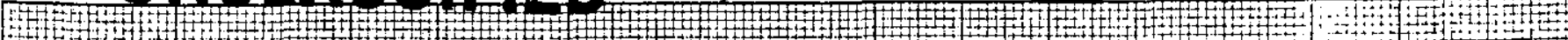

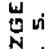

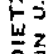

$\frac{\omega}{2}$

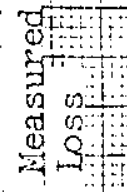

(1)

至

$+\sum_{i=1}$

$\sim$ जे

刃े:-

in

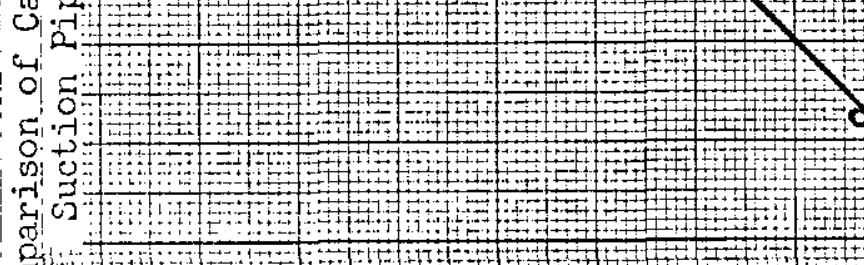




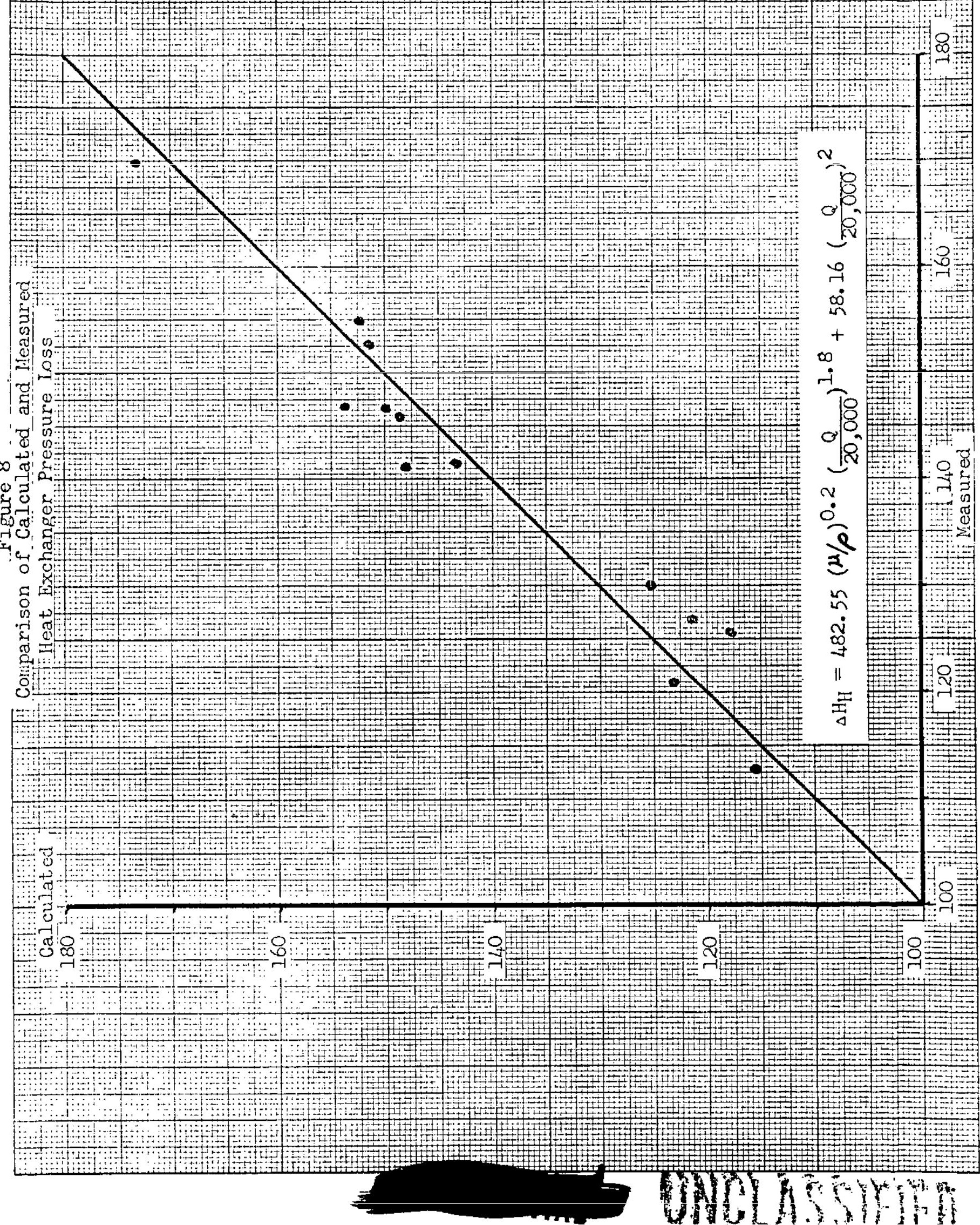


Figure 9

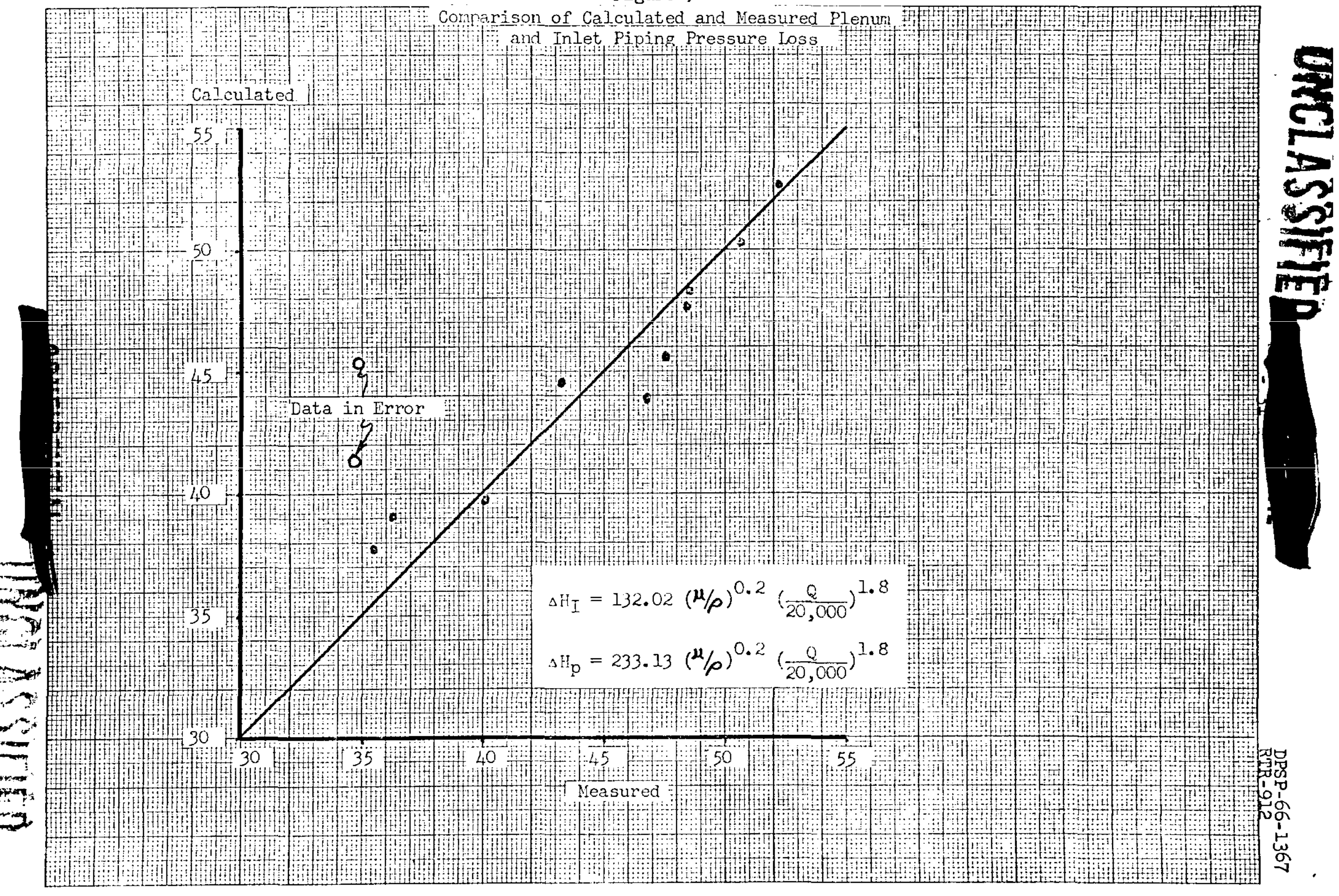




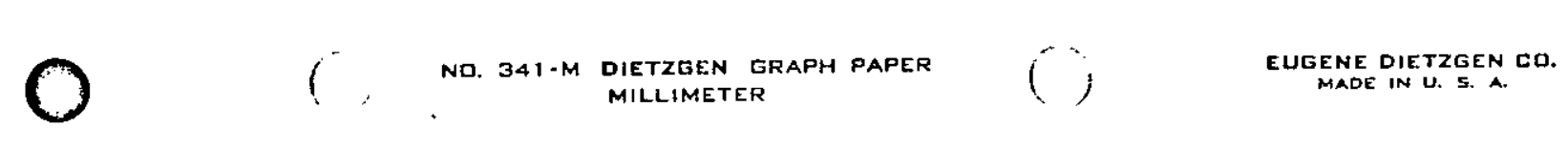

'Figure 12

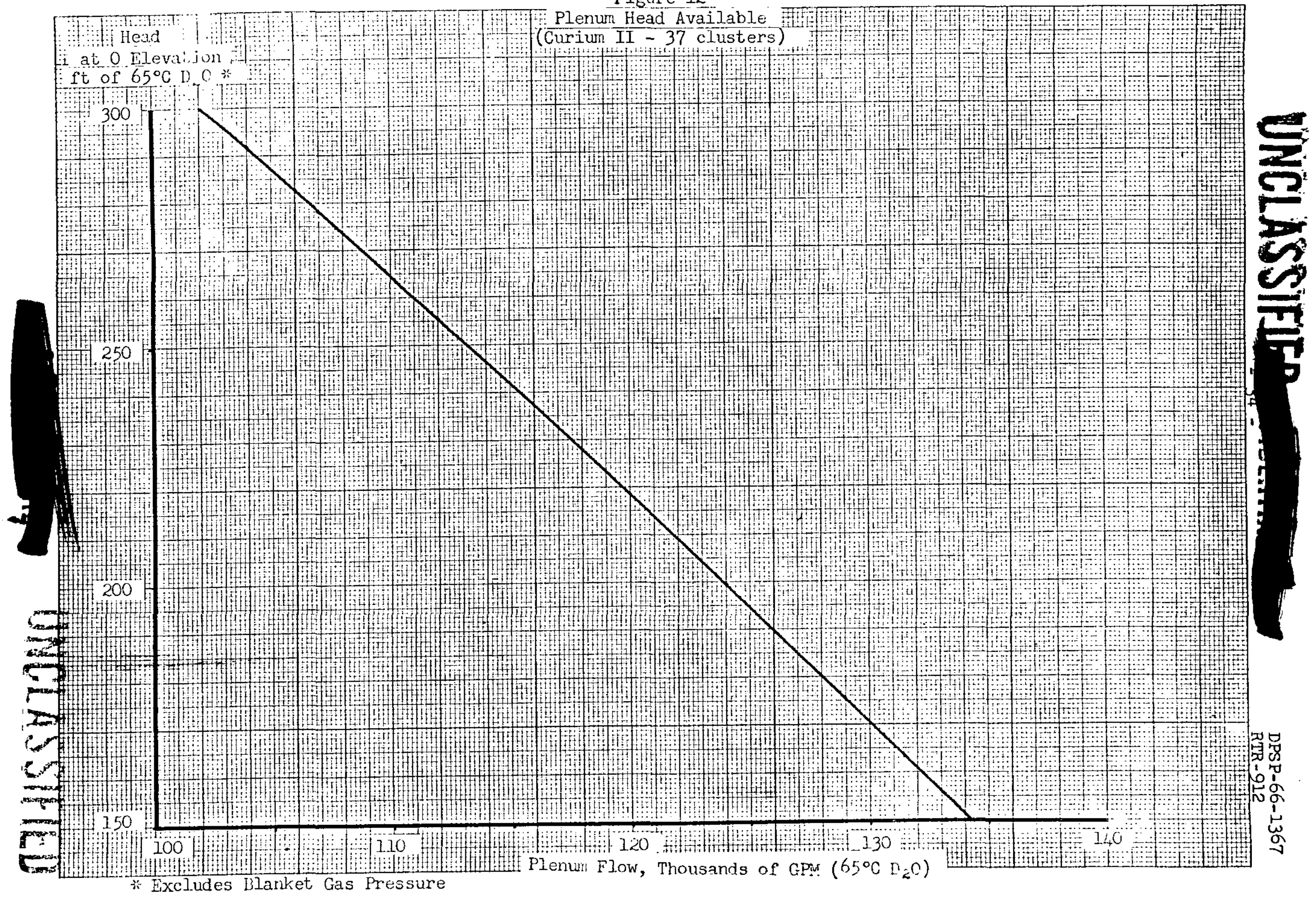




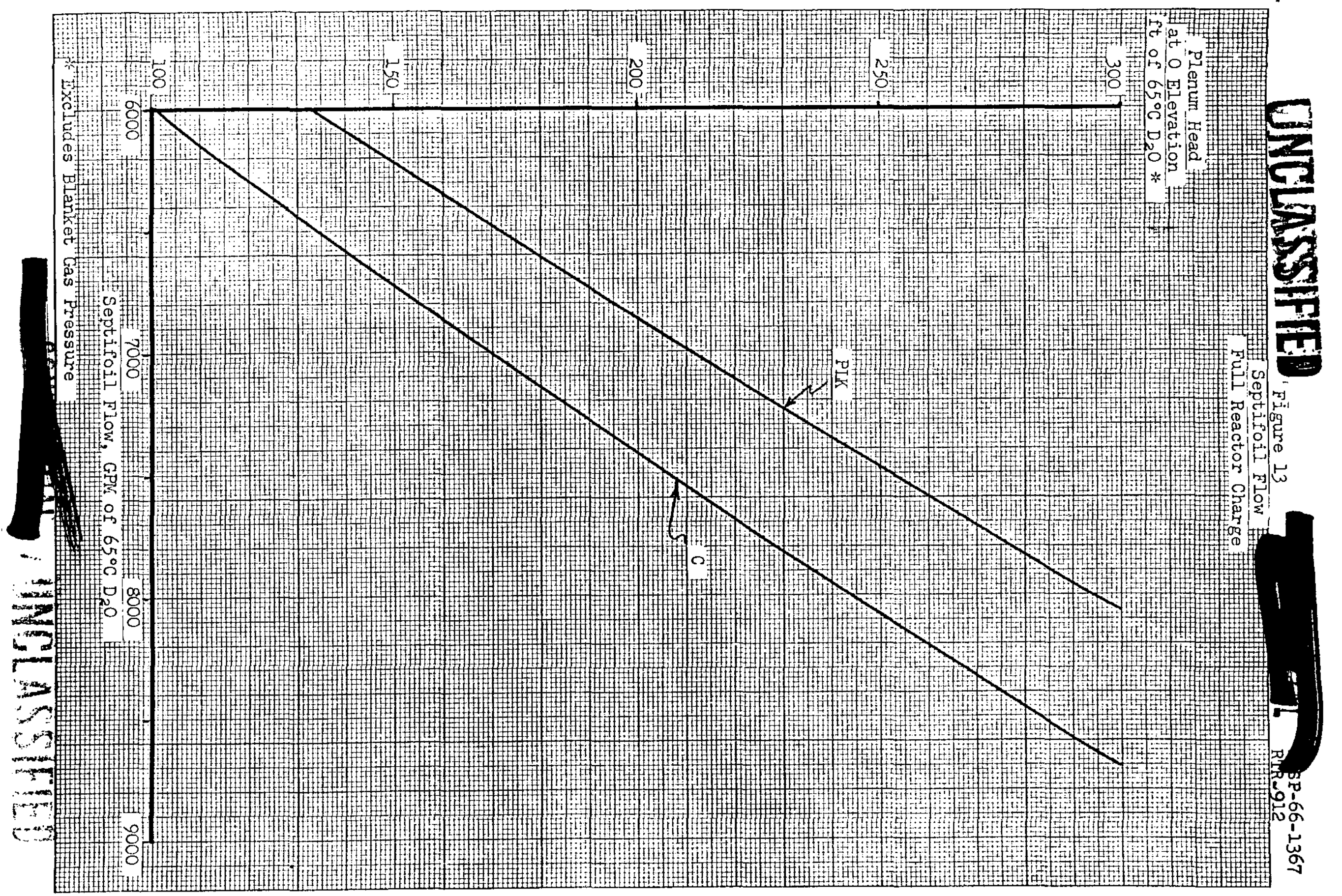




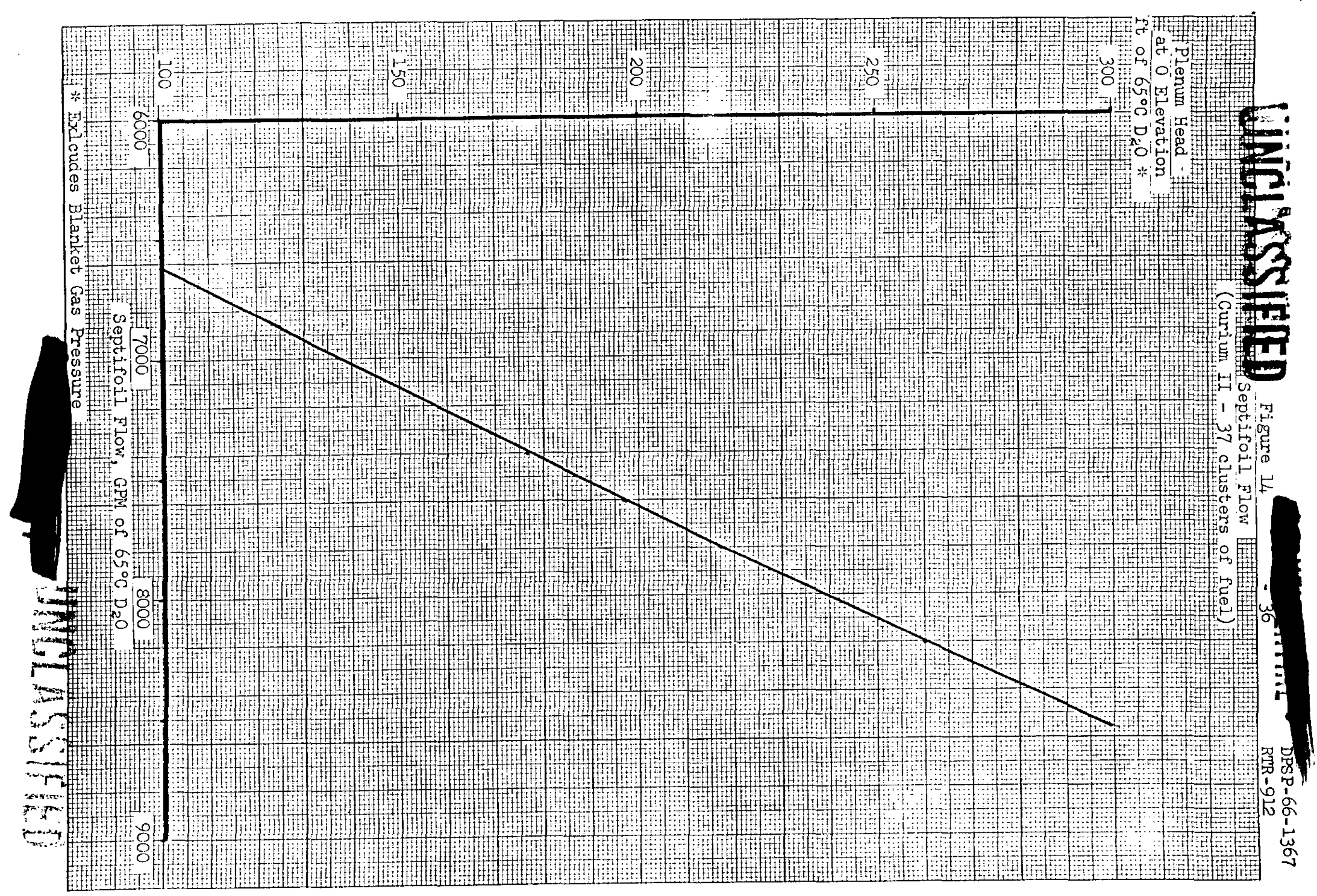




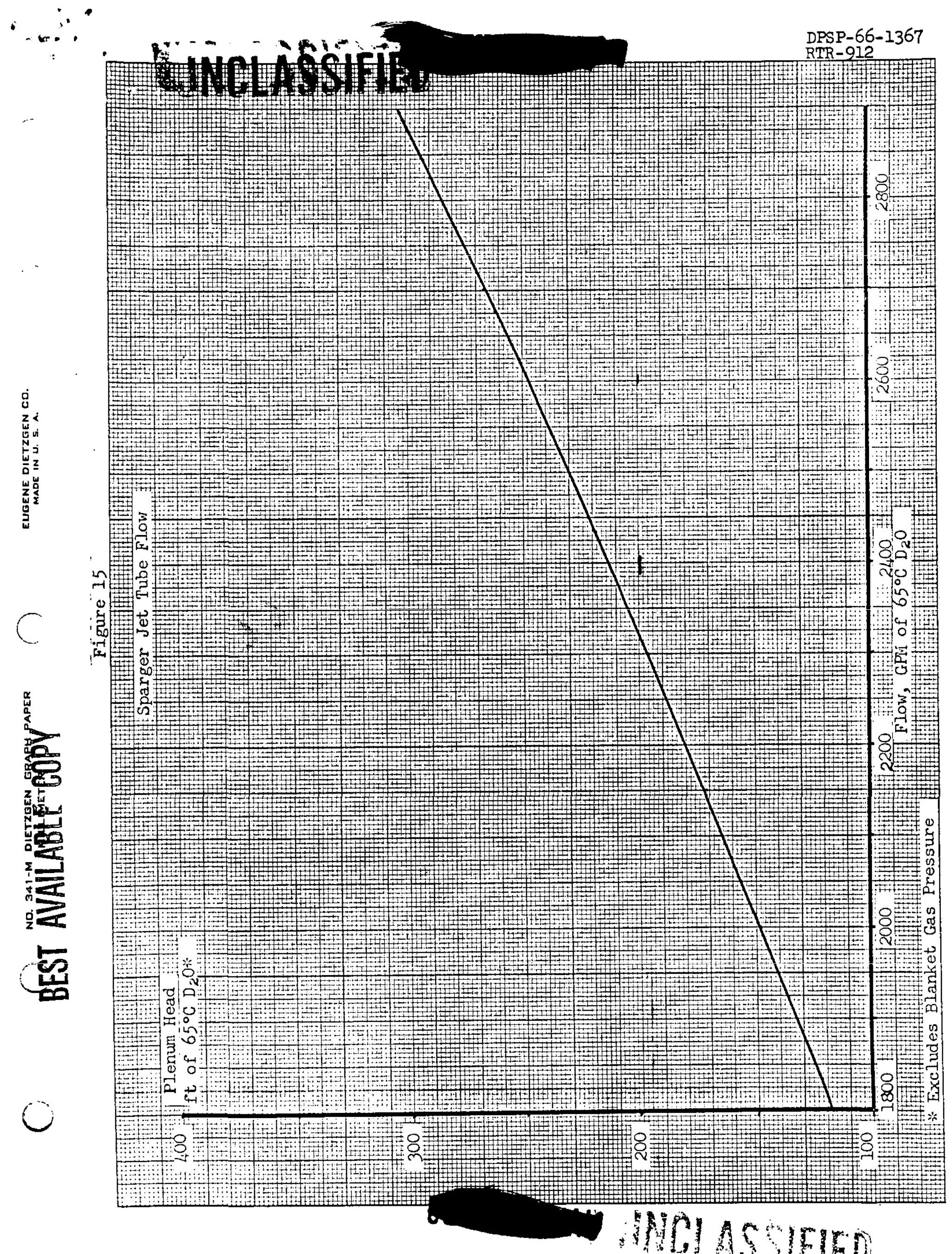




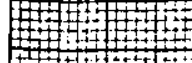

